\title{
Effects of Environmental and Pathological Hypoxia on Male Fertility
}

\begin{abstract}
Zhibin Lit,2t, Sumin Wang ${ }^{1 t}$, Chunli Gong ${ }^{1+}$, Yiyang Hu${ }^{1}$, Jiao $\mathrm{Liu}^{3}$, Wei Wang Yang Chen ${ }^{1}$, Qiushi Liao ${ }^{1}$, Bing He ${ }^{1,4}$, Yu Huang ${ }^{1}$, Qiang Luo ${ }^{1}$, Yongbing Zhao ${ }^{1 *}$ and Yufeng Xiao ${ }^{1 *}$

${ }^{1}$ Department of Gastroenterology, Xinqiao Hospital, Third Military Medical University, Chongqing, China, ${ }^{2}$ Key Laboratory of Extreme Environmental Medicine, Ministry of Education of China, Chongqing, China, ${ }^{3}$ Department of Endoscope, The General Hospital of Shenyang Military Region, Liaoning, China, ${ }^{4}$ Department of Laboratory Medicine, General Hospital of Northern Theater Command, Shenyang, China
\end{abstract}

OPEN ACCESS

Edited by:

Zhao-Jia Ge,

Qingdao Agricultural University, China

Reviewed by:

Marziyeh Tavalaee,

Royan Institute, Iran

Ricardo Miyaoka,

State University of Campinas, Brazil

Ricardo Daniel Moreno,

Pontificia Universidad Católica

de Chile, Chile

*Correspondence:

Yongbing Zhao

527365196@qq.com

Yufeng Xiao

xiaoyufeng@tmmu.edu.cn

${ }^{\dagger}$ These authors have contributed equally to this work and share first authorship

Specialty section:

This article was submitted to Molecular and Cellular Reproduction, a section of the journal Frontiers in Cell and Developmental

Biology

Received: 16 June 2021

Accepted: 23 August 2021

Published: 13 September 2021

Citation:

Li Z, Wang S, Gong C, Hu Y, Liu J, Wang W, Chen Y, Liao Q, He B, Huang $Y, L$ Lo $Q$, Zhao $Y$ and Xiao $Y$ (2021) Effects of Environmental and Pathological Hypoxia on Male

Fertility.

Front. Cell Dev. Biol. 9:725933. doi: 10.3389/fcell.2021.725933
Male infertility is a widespread health problem affecting approximately $6 \%-8 \%$ of the male population, and hypoxia may be a causative factor. In mammals, two types of hypoxia are known, including environmental and pathological hypoxia. Studies looking at the effects of hypoxia on male infertility have linked both types of hypoxia to poor sperm quality and pregnancy outcomes. Hypoxia damages testicular seminiferous tubule directly, leading to the disorder of seminiferous epithelium and shedding of spermatogenic cells. Hypoxia can also disrupt the balance between oxidative phosphorylation and glycolysis of spermatogenic cells, resulting in impaired self-renewal and differentiation of spermatogonia, and failure of meiosis. In addition, hypoxia disrupts the secretion of reproductive hormones, causing spermatogenic arrest and erectile dysfunction. The possible mechanisms involved in hypoxia on male reproductive toxicity mainly include excessive ROS mediated oxidative stress, HIF-1 $\alpha$ mediated germ cell apoptosis and proliferation inhibition, systematic inflammation and epigenetic changes. In this review, we discuss the correlations between hypoxia and male infertility based on epidemiological, clinical and animal studies and enumerate the hypoxic factors causing male infertility in detail. Demonstration of the causal association between hypoxia and male infertility will provide more options for the treatment of male infertility

Keywords: hypoxia, infertility, sperm, spermatogenic cells, spermatogenesis, HIF-1 $\alpha$

\section{INTRODUCTION}

The clinical definition of infertility is described as the failure of couples to conceive after more than 1 year of regular unprotected intercourse (Zegers-Hochschild et al., 2009). According to the World Health Organization statistics, infertility has become a global public health issue, affecting approximately 12\%-15\% of couples worldwide (Practice Committee of the American Society for Reproductive Medicine, 2015). Male factors are responsible for $50 \%$ of the cases of infertility, among which $20 \%-30 \%$ occur solely due to male factors, and $20 \%-30 \%$ are due to factors affecting both partners (Tournaye et al., 2017). Data from a global burden of disease (GBD survey suggested that the prevalence of male infertility increased by $0.291 \%$ per year from 1990 to 2017 globally (Sun et al., 2019), and may approach the $50 \%$ limit. Currently, male infertility is not just a quality-oflife problem, but a political theme with considerable social distress, and it imposes a substantial financial burden on couples and health-care systems (Agarwal et al., 2021). 
The causes of male infertility are wide-ranging, including obesity, psychological stress and environmental pollutants, and hypoxia is one of the predominant reasons (Gat et al., 2006, 2005). Hypoxia is defined as a transient or sustained condition of decreased arterial oxygen partial pressure resulting in tissue oxygen deficiency, which is characterized by a decrease in arterial oxygen partial pressure and oxygen content (Reyes et al., 2012). In humans, the arterial oxygen partial pressure $\left(\mathrm{PaO}_{2}\right)$ is $12-$ $13.3 \mathrm{Kpa}(90-100 \mathrm{mmHg})$ and the arterial oxygen saturation $\left(\mathrm{SaO}_{2}\right)$ is $92-96 \%$ during normal conditions at sea level. Hypoxia occurs when $\mathrm{SaO}_{2}$ drops below 90\% (Bomhard and Gelbke, 2013). In mammals, two types of hypoxia are known, including environmental hypoxia and pathological hypoxia. The former mainly refers to low partial pressure of inhaled oxygen caused by high altitude, while the latter is impaired testicular oxygen delivery or utilization caused by pathological factors, including varicocele (Jensen et al., 2017), chronic lung disease (Semple et al., 1983), sleep apnea (Mesarwi et al., 2019) and sickle cell disease (Torres et al., 2014). Both environmental and pathological hypoxia have been shown to negatively affect male fertility in animals and humans, which can lead to a reduced sperm count, low sperm motility and abnormal sperm morphology on sperm output (Ata-Abadi et al., 2020; Wang J. et al., 2020). However, the adverse consequences of hypoxia on male fertility have been established in some studies, but it is difficult to make a firm conclusion without enough evidence. In this review, we summarize the effects of hypoxia on various aspects of fertility based on basic and clinical evidence in great detail, and discuss the potential mechanisms. Finally, we enumerate the environmental and pathological hypoxic factors causing male infertility. A correct understanding of the relationship between hypoxia and male infertility will provide more ideas about the etiological diagnosis of male infertility and more options for its treatment.

\section{OVERVIEW OF HYPOXIA}

Oxygen began to accumulate in the atmosphere approximately 2.5 billion years ago and reached its present level $(\sim 21 \%)$ about 350 million years ago (Bekker et al., 2004). The crucial function of oxygen is to act as a terminal electron acceptor to participate in aerobic respiration, which converts the chemical energy in cells into the active chemical energy in ATP through oxidative phosphorylation. Energy produced by aerobic respiration is sufficient to support physicochemical reactions in living cells and is incapable being sustained by glycolysis alone under hypoxic conditions (Semenza, 2012).

The evolution of the respiratory system and cardiovascular system allowed atmospheric oxygen to be transported to tissues directly through the bloodstream in more complex metazoans, such as Homo sapiens. When environmental oxygen content is low or respiratory or cardiovascular systems are impaired, hypoxia occurs (MacIntyre, 2014). Most mammals show little tolerance to hypoxia and their response involves the activation of regulatory mechanisms at systemic, tissue and cellular levels. The key factor in oxygen adaptation is hypoxia inducible factor
(HIF) (Choudhry and Harris, 2018). Structurally, HIF is a heterodimer comprised of $\alpha$ and $\beta$ subunits, and each subunit contains basic helix-loop helix PAS domains for DNA binding (Wang et al., 1995). Under normal oxygen conditions, the proline hydroxylases (PhDs) family (also known as the Egin or $\mathrm{HPH}$ family) hydroxylates one or both highly conserved proline residues near NTAD, which generates a binding site for the von Hippel Lindau ( $\mathrm{pVHL}$ ) tumor suppressor protein, a component of the ubiquitin ligase complex, leading to ubiquitination degradation of HIF- $\alpha$ (Choudhry and Harris, 2018). The PHD is inactive when oxygen is not available, allowing HIF- $\alpha$ to stabilize and accumulate gradually, dimerizing with HIF- $\beta$ (Semenza, 2012). Upon dimerization, HIF translocates to the nucleus and binds to hypoxia response elements (HREs) to play a transcriptional regulatory role in target genes (Figure 1) (Majmundar et al., 2010).

HIF- $1 \alpha$ mRNA is expressed equally in all male reproductive systems, including the testis, all segments of the epididymis, ductus deferens, accessory sex glands, and penis (Powell et al., 2002). In the testes of rats, immunoblot and immunohistochemical analysis revealed that HIF- $1 \alpha$ protein was expressed in almost every epididymal epithelium and was significantly higher in hypoxic testes than in normoxic testes (Liang et al., 2015; Zhang et al., 2016). In humans, the expression of HIF- $1 \alpha$ protein was 7 times higher in patients with varicocele (testicular hypoxia) than in normal volunteers (Lee et al., 2006). Widespread expression of HIF-1 $\alpha$ is the basis of hypoxic adaptation in the male reproductive system.

\section{REPRODUCTIVE CONSEQUENCES OF HYPOXIA}

\section{Reduced Sperm Quality}

The sperm quality outcome measures are the sperm concentration, motility, morphology, semen volume, viability and DNA fragmentation, which are the parameters most frequently used in clinical settings (Schisterman et al., 2020). Growing evidence has shown that hypoxia has adverse effects on sperm quality in several species, including rodents, livestock, Drosophila, fish, and humans (Wang et al., 2016; Cofre et al., 2018; Wang J. et al., 2020). In rats and mice, acute, intermittent and chronic hypoxia reduced the total sperm concentration and sperm motility while increasing the rates of sperm DNA fragmentation and abnormal sperm morphology (Vargas et al., 2011; Torres et al., 2014; Bai et al., 2018; Wang J. et al., 2020; Ma et al., 2021). Hypoxia in rams led to a lower sperm count, sperm progressive motility and viability than in normoxic rams (Cofre et al., 2018). In humans, male soldiers exposed to hypoxia at high altitude $(5380 \mathrm{~m})$ for 12 months showed a poor sperm concentration, sperm motility, sperm density, and survival rate compared with those at 1 month before exposure ( $\mathrm{He}$ et al., 2015). Similar observations were made among mountain trekkers, expeditions and specimens (Donayre et al., 1968; Okumura et al., 2003; Verratti et al., 2008). Furthermore, hypoxia mediated transgenerational impairments in sperm quality. Studies from hypoxic fish proved that exposing the Fo generation 


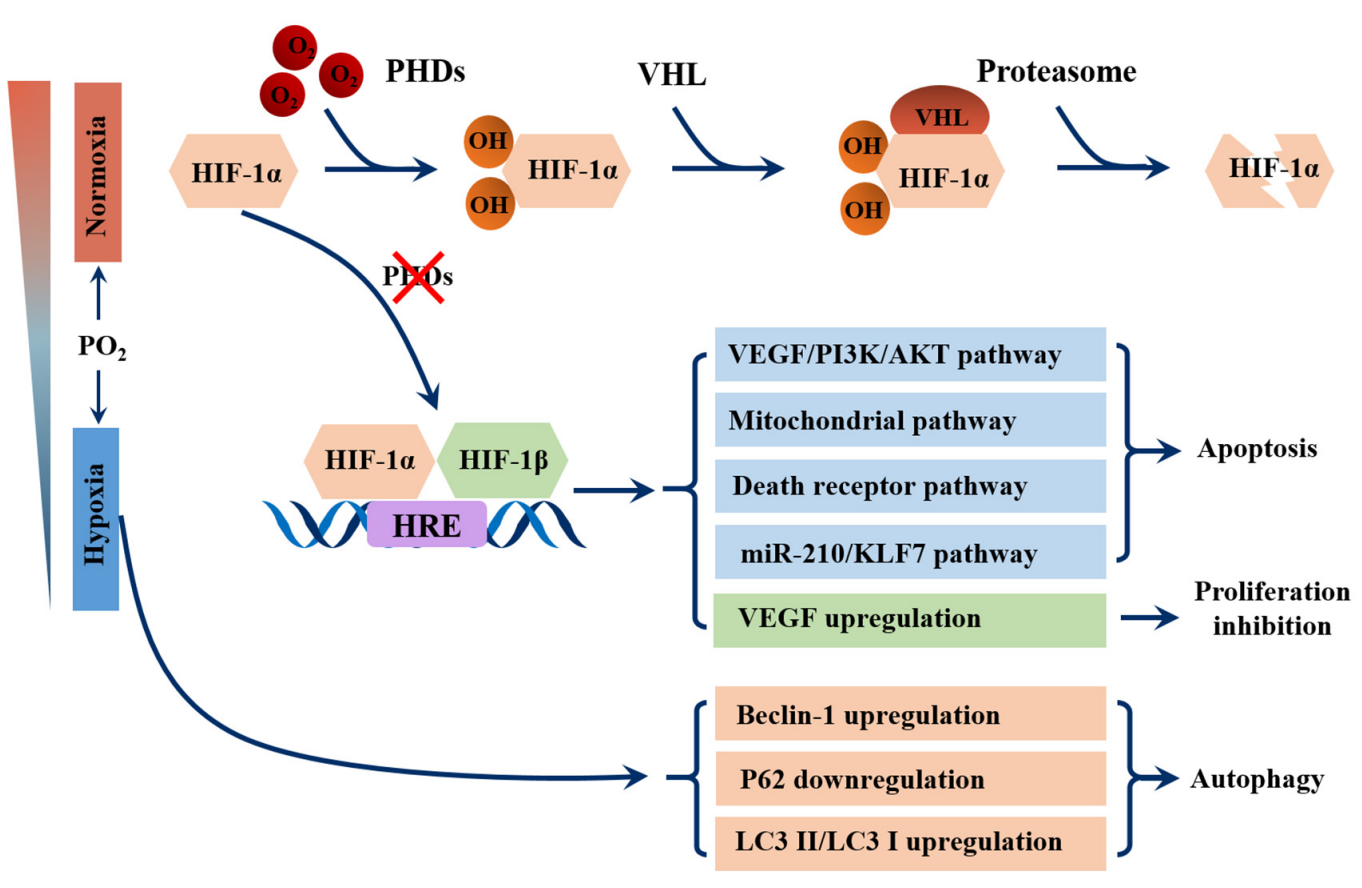

FIGURE 1 | Schematic overview of the pathways involved in germ cell damage caused by HIF-1 $\alpha$. In the presence of oxygen, prolyl hydroxylases (PHDs) hydroxylate the HIF-1 $\alpha$, which generates a binding site for the von Hippel Lindau (VHL) protein, a component of the ubiquitin ligase complex, leading to proteasomal degradation of HIF- $\alpha$. During hypoxia, the enzymatic activity of PHDs is inhibited, leading to stabilization of HIF-1 $\alpha$ subunits. After translocation to the nucleus, they complex with their $\beta$ subunit and bind to hypoxia responsive elements (HREs). The genes activated by HIF perform the following functions in germ cells: apoptosis, which is caused by VEGF/PI3K/AKT signaling pathway, mitochondrial pathway, death receptor pathway and miR210/KLF7 pathway; Proliferation inhibition, which is caused by activating VEGF transcription. Hypoxia can also upregulate the expression of Beclin-1 and LC3II/LC3I, and downregulate the expression of P62 to promote germ cell autophagy.

to hypoxia led to a decrease in sperm count and motility in the F1 and F2 generations that had never been previously exposed to hypoxia (Wang et al., 2016; Lai et al., 2018).

It is worth noting that patients or animals with pathological hypoxia such as sickle cell disease (Friedman et al., 1974; Nahoum et al., 1980; Osegbe et al., 1981; Agbaraji et al., 1988; Modebe and Ezeh, 1995; Berthaut et al., 2008), thalassemia (De Sanctis et al., 2008; Safarinejad, 2008a), lung diseases (Charpin et al., 1985) and obstructive sleep apnea hypopnea syndrome (Torres et al., 2014) also showed decreased sperm parameters of sperm output. Taking sickle cell disease as an example, D N Osegbe et al. measured different semen parameters including sperm motility, density, morphology, semen, viscosity, volume, $\mathrm{pH}$ and liquefaction time produced by 40 male patients aged 20.56 years with sick cell disease, and found that the semen parameters of all sickle cell subjects did not meet the minimum requirements for fertility (Osegbe et al., 1981). Subfertility seems to be a great problem among these patients with sickle cell disease, because they have rarely fathered children (Akinla, 1972).

\section{Impaired Spermatogenesis}

Successful fertility requires a large amount of normal sperm. In order to meet the minimum fertility standard, the sperm concentration is greater than 15 million per $\mathrm{ml}$, of which at least $40 \%$ should be motility and at least $4 \%$ with a normal morphology according to the new criteria for the laboratory examination of human sperm parameters of WHO [World Health Organization (WHO), 2010]. The generation of sperm is depended on a highly dynamic cellular differentiation process in the seminiferous tubules of the testis, called spermatogenesis (Griswold, 2016). This process begins with the self-renewal and differentiation of spermatogonial stem cells (SSCs) (Yeh et al., 2011). Self-renewal and differentiation of spermatogonial stem cells must be able to self-renew to maintain stem cell populations and undergo differentiation to form sperm, and this relationship between proliferation and differentiation rates is a parameter highly influenced by oxygen availability (Yeh et al., 2011). It is well established that cells mainly undergo oxidative phosphorylation to produce ATP in the presence of sufficient oxygen supply, while in the absence of oxygen, ATP is produced by glycolysis. However, stem cells, as well as SSCs, rely more on glycolysis for ATP production to avoid DNA damage caused by excessive ROS produced by oxidative phosphorylation, but oxidative phosphorylation and oxidative phosphorylation are also essential, since ROS are also required for SSC self-renewal (Morimoto et al., 2013; Ryall et al., 2015). This is a bioenergenic balance between glycolysis and oxidative phosphorylation, which can be disrupted in the absence of oxygen. Recent research has found that the inhibition of mitochondrial respiration and glycolysis 
in undifferentiated spermatogonia cells results in decreased spermatogonial colony size, and reduced expression of SSC marker genes, such as Plzf, Id4, Gfro1, Etv5, and Sall4, suggesting that hypoxia may affect spermatogonia differentiation (Chen et al., 2020).

Following self-renewal and differentiation, SSCs transform into primary spermatocytes, which undergo two meiotic divisions to reduce the chromosome number from diploid to haploid and diversify the genetic material to form round spermatids (Lloyd and Bomblies, 2016); Considering that the seminiferous tube is thicker in diameter and lacks a vascular supply, oxygen reaches the lumen only by diffusion. Due to the limited diffusion distance and the high oxygen consumption of spermatogenesis, luminal $\mathrm{PO}_{2}$ is likely to be very low (Wenger and Katschinski, 2005). Therefore, spermatocytes appear to have less access to oxygen than SSCs (Cross and Silver, 1962; Wenger and Katschinski, 2005). Although few studies have focused on oxygen and energy metabolism in spermatocyte meiosis, it is undeniable that hypoxia is bound to increase the energy burden of meiosis, since meiosis is an extremely energy-intensive process. Thus it is not surprising that the apoptosis rate of spermatocytes is much higher than that of other germ cells under most hypoxic conditions (Liao et al., 2010).

Hypoxia affects not only germ cells but also the seminiferous tubule. Findings from hypoxic rats confirmed that exposing rats to hypoxic conditions arrested spermatogenic development, misshaped the arrays of spermatids (Bai et al., 2018), atrophied and thinned the seminiferous tubule lumen (Wang J. et al., 2020), decreased the cellularity of the seminiferous epithelium (Cikutovic et al., 2009; Liao et al., 2010), and disturbed the stages of the seminiferous epithelium (Gasco et al., 2003; Gonzales et al., 2004). Similar phenotypes pertaining to other animals such as mice (Kastelic et al., 2019) and rhesus monkeys (Saxena, 1995), have also been reported. In addition, Sertoli cells, the only type of somatic cells in the seminiferous epithelium of the testis that are essential for the maintenance of cell junctions, nutrient supply, and germ cells mitosis and meiosis (Ni et al., 2019), are also affected by hypoxia. A study using a hypobaric chamber simulating hypoxic condition at an altitude of $5000 \mathrm{~m}$ showed that 3 weeks of persistent hypoxic exposure resulted in a decrease in the number of Sertoli cells in rats (Bai et al., 2018). The number of Sertoli cells were also decreased under acute hypobaric hypoxia conditions (Shevantaeva and Kosyuga, 2006).

\section{Reproductive Hormone Disorders}

As part of the body's adaptation to hypoxia, the hypothalamicadrenal-adrenal (HPA) axis regulates the functions of the hypothalamic-adrenal-gonadal (HPG) axis, which is necessary to ensure successful reproduction of males. The HPG axis influences the function of the reproductive system through the endocrine pathway, originating from the secretion of gonadotropin-releasing hormone $(\mathrm{GnRH})$ in the hypothalamus. GnRH stimulates the pituitary gland to synthesize and secrete follicle-stimulating hormone (FSH) and luteinizing hormone (LH) (Neto et al., 2016). In turn, FSH and LH act on the testes to promote androgen (main testosterone) synthesis. GnRH, FSH,
$\mathrm{LH}$ and testosterone are the major reproductive hormones that affect male reproductive functions.

The functions of FSH, $\mathrm{LH}$ and testosterone are mediated by their specific receptors, FSH receptor (FSHR), LH receptor (LHR), and androgen receptor (AR) respectively (Oduwole et al., 2018). FSH receptor is mainly expressed on Sertoli cells, which affects the maturation, proliferation, and function of Sertoli cells (Griswold, 1998; Abel et al., 2008). Mutations of FSH or FSHR have been associated with a decreased Sertoli cell number and sperm count, but have no effect on fertility (Tapanainen et al., 1997). LH receptor is expressed on Leydig cells to stimulate testosterone production (Narayan, 2015). The functions of testosterone are mediated by the androgen receptor (AR). Androgen receptor is generally expressed on Sertoli cells, Leydig cells and arteriole smooth muscle in the testis, but not in germ cells (Sar et al., 1990; Bremner et al., 1994; Wang et al., 2009; Smith and Walker, 2014). Findings from cell specific AR ablation or overexpression models showed that testosterone is crucial for spermatogonia number maintenance, blood-testis barrier integrity, completion of meiosis and the adhesion of spermatids and spermiation (Wang et al., 2009; Smith and Walker, 2014; O'Hara and Smith, 2015).

Through the years, although researches on hypoxia and reproductive hormones has made great progress, many contradictory reports still exist in both hypoxic animals and humans. Most studies have suggested that both environmental and pathological hypoxia decrease the levels of FSH and $\mathrm{LH}$ in the blood circulation (Dada and Nduka, 1980; el-Hazmi et al., 1992; Farias et al., 2008), while few studies have shown no effect or increased FSH or LH levels (He et al., 2015; Verratti et al., 2016). In addition, studies on the effects of hypoxia on testosterone secretion were also widely divergent. Several studies in humans and animals suggested that hypoxia stimulates testosterone production (Boksa and Zhang, 2008; Ma et al., 2018; Cho et al., 2019), while others suggested the opposite (Wang et al., 2017, 2019; Bai et al., 2018; Raff et al., 2018; Kim and Cho, 2019). Interestingly, similar findings were observed in cell models. One study in mouse Leydig cell line TM3 cells in a hypoxic incubator chamber showed increased testosterone release, and these effects were mediated by increased vascular endothelial growth factor (VEGF) production (Hwang et al., 2007); Another study in which rat primary Leydig cells or TM3 cells were exposed to hypoxia $\left(1 \% \mathrm{O}_{2}\right)$ indicated a negative regulation of testosterone synthesis under hypoxia. This decline may be related to HIF-1 $\alpha$ mediated transcriptional suppression of steroidogenic acute regulatory protein (Star), a rate-limiting enzyme for testosterone synthesis (Wang et al., 2018).

Actually, most of these conflicting reports are to be expected since testosterone is both a hypoventilatory and an erythropoietic hormone (Molinari, 1982; Guo et al., 2014; Marques et al., 2020). In the early stage of hypoxia (or acute hypoxia exposure), an increased in serum testosterone prevents respiratory alkalosis caused by exaggerated respiratory response of the organism (Gonzales, 2013). An increase in serum testosterone may also enhance erythropoiesis, supporting acclimatization (Gonzales, 2013). With the prolongation of hypoxia, ROS gradually accumulates in testicular cells leading to the damage of Leydig 
cells, which causes the decrease of testosterone. Thus it is not surprising that Madrid et al. observed an increased in testosterone during the first $24 \mathrm{~h}$ followed by a decrease on the 5th day in normobaric hypoxic murine model (Madrid et al., 2013).

\section{Erectile Dysfunction}

Erectile dysfunction is a common male sexual dysfunction that is defined as the inability of the penis to attain or maintain a sufficient erection to achieve satisfactory sexual intercourse (Hatzimouratidis et al., 2010). Erectile dysfunction affects physical and psychosocial health, and has been identified as a common medical disorder over the past 20 years (Rathore et al., 2019). Causes of erectile dysfunction can be divided into 2 types: psychogenic disorders and an organic etiology. Current studies have suggested that psychogenic disorders contribute to only $20 \%$ of patients, and more than $80 \%$ of sufferers have an organic etiology (Yafi et al., 2016). There are two causes of organic etiology: endocrine and non-endocrine. Of the edocrinological erectile dysfunctions, testosterone plays important roles in enhancing sexual desire and erections (Shamloul and Ghanem, 2013); In terms of non-edocrinological erectile dysfunction, vasculogenic factors including arterial inflow disorders and corporeal veno-occlusion are the most common (Yafi et al., 2016). Notably, hypoxia can affect both types of ED mentioned above simultaneously. Hypoxia can lead to a disturbance (mostly reduction) of testosterone secretion, as described in the previous section "Reproductive hormone disorders", which is the main cause of edocrinological erectile dysfunctions. Hypoxia from decreased corpora cavernosal oxygenation results in a decrease in prostaglandin E1 levels, which play a role in inhibiting pro-fibrotic cytokines, including transforming growth factor $\beta 1$ (TGF $\beta 1$ ). These pro-fibrotic cytokines promote collagen deposition, replacing the smooth muscle and resulting in decreased elasticity of the penis. As the smooth muscle to collagen ratio decreases and collagen content increases, the ability of the cavernosa to compress the subtunical veins decreases, leading to corporal veno-occlusive dysfunction (Yafi et al., 2016).

Findings from several animal models of disease and clinical reports suggested that hypoxia impairs NO synthesis, which in turn decreases the functional integrity of penile smooth muscles (Moreland, 1998; Saenz de Tejada et al., 2004). A murine model of chronic intermittent hypoxia showed that 1 weeks of chronic intermittent hypoxia exposure resulted in a 55\% decline in daily spontaneous erections. After 5 weeks of exposure, non-contact sexual activity was significantly suppressed, latencies for mounts and intromissions increased by 60 - and 40-fold, respectively, and the sexual activity index decreased 6-fold (Soukhova-O'Hare et al., 2008). Another study performed in rats found that chronic intermittent hypoxia exposure significantly decreased the ratio of intracavernous pressure(ICP) to mean arterial blood pressure (MAP), an indicator of penile erectile response, at all levels (2.5, 5.0 , and 7.5 volts) compared with normoxic rats. Furthermore, higher of apoptotic index and lower smooth muscle/collagen of corpus cavernosum were observed in hypoxic rats than normoxic (Moreland, 1998; Zhu et al., 2015). In humans, a study of hypoxia associated with idiopathic pulmonary fibrosis showed that the severity of hypoxia was closely associated with degree of testosterone suppression, which led to erectile dysfunction (Semple P. D. et al., 1984).

\section{POTENTIAL MECHANISMS BY WHICH HYPOXIA CAUSES MALE INFERTILITY}

\section{Excessive ROS Mediates Oxidative Stress}

Reactive oxygen species (ROS), including superoxide anions (O2•), hydrogen peroxide $\left(\mathrm{H}_{2} \mathrm{O}_{2}\right)$, peroxyl (ROO•), and hydroxyl $(\mathrm{OH} \bullet)$ radicals, participate in almost all cell physiological processes as signaling molecules (Boveris and Chance, 1973; Du Plessis et al., 2015). In the testis, the physiological level of ROS is beneficial for SSCs selfrenewal, germ cell proliferation, maturation and sperm capacitation, acrosome reaction, hyperactivation, and the fusion of spermatozoa with the oocyte (Ford, 2004; Agarwal et al., 2012; Morimoto et al., 2013; Bejarano et al., 2014; Aitken, 2017). However, excessive levels of ROS can promote the cell reductiveoxidative balance to an oxidative state, leading to oxidative stress, and thereby damaging the physiological functions of proteins, lipids and DNA.

Although conventional wisdom holds that exposure of cells to excess oxygen leads to the generation of ROS, studies have shown that exposure of cells to hypoxic conditions also leads to increased excessive ROS generation (Kim et al., 2006; Yadav et al., 2019; Zhao et al., 2020). As early as 1943, John Macleod discovered that increased production of $\mathrm{H}_{2} \mathrm{O}_{2}$ led to a decrease in sperm motility, this was a breakthrough that opened a pathway for research on the role of ROS in sperm function. In sperm, the sources of ROS are mainly the sperm mitochondria, cytosolic L-amino acid oxidases, and plasma membrane nicotinamide adenine dinucleotide phosphate oxidases (Aitken, 2017) (Figure 2). Findings from past studies have linked excessive ROS to poor sperm quality and male infertility (Ford, 2004; Tremellen, 2008), and up to $30 \%-80 \%$ of the pathology of infertility is attributed to ROS-mediated sperm damage (Aitken and Fisher, 1994; Agarwal et al., 2006, 2019). Reactive oxygen species causes infertility in two principal ways. First, ROS causes membrane lipid peroxidation, that disturbs its fluidity, resulting in damage to the sperm membrane and thus affecting sperm motility and its ability to fuse with the vitelline membrane of oocytes due to the resulting damage to the sperm membrane. Second, ROS acts directly on sperm DNA, causing DNA double or single-strand breaks, which weakens the paternal genomic contribution to the embryo (Tremellen, 2008). Data from numerous studies have highlighted that ROS had significant negative effects on spermatogenesis (Liu B. et al., 2019; Sharma et al., 2019), steroidogenesis (Chen et al., 2010; Tai and Ascoli, 2011), and epididymal sperm maturation (ArenasRios et al., 2016; Schneider et al., 2020). Furthermore, ROS can also mediate germ cell apoptosis by activating mitochondrial and death receptor apoptotic pathways, which may be the main cause of sperm count reductions (Ghosh and Mukherjee, 2018; Liu T. et al., 2019) (Figure 2). 


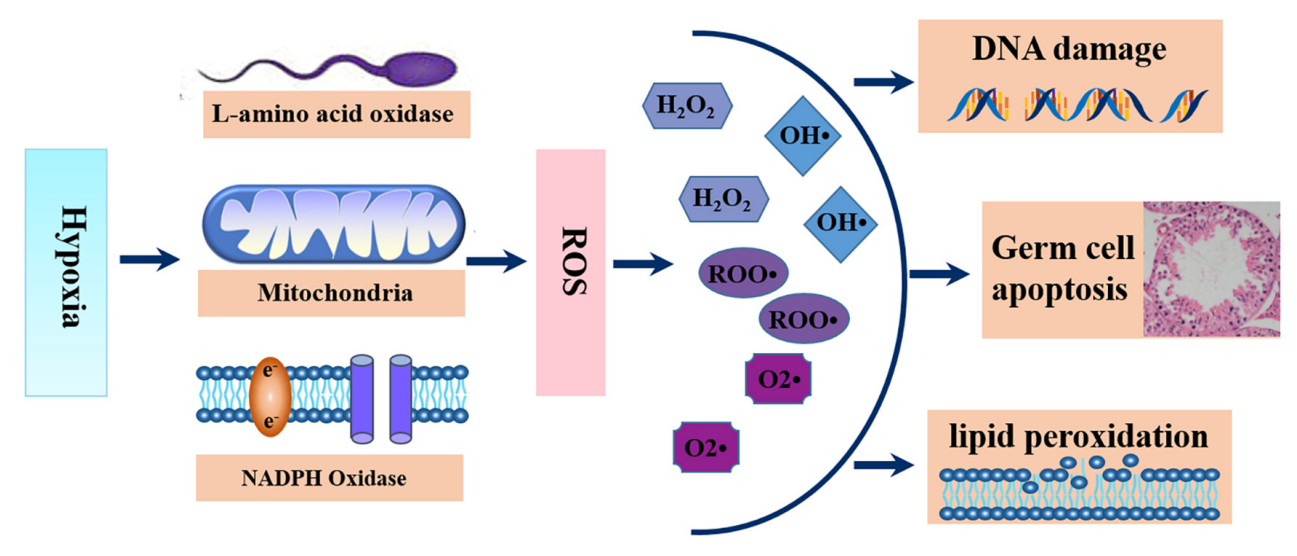

FIGURE 2 | Schematic diagram of the generations and functions of ROS. Hypoxic exposure stimulates the generation of excess ROS from sperm mitochondria, cytosolic L-amino acid oxidases, and plasma membrane nicotinamide adenine dinucleotide phosphate oxidases, leading to sperm lipid peroxidation, sperm DNA damage and germ cell apoptosis.

\section{HIF-1 $\alpha$ Mediates Germ Cell Apoptosis and Proliferation Inhibition}

Programmed cell death, which we call apoptosis, is a critical biological process for regulating both the size and the quality of male germ cells and controlling the sperm output. In fact, only $25 \%$ of germ cells achieve maturity during spermatogenesis, and more than $75 \%$ of the sperm yield were lost through apoptosis in any phase of spermatogenesis (Aitken et al., 2011). Under physiological conditions, apoptosis plays an important role in the elimination of damaged germ cells, avoiding the passage of defects to future generations (Shaha et al., 2010). However, dysregulated apoptosis of germ cells was indicated in the etiology of male infertility, since increased apoptosis of cells has been observed in the testes of infertile men or animal models (Lin et al., 1997; Fouchecourt et al., 2016; Liu P. et al., 2018; Mu et al., 2018).

Previous studies have shown that hypoxia is a powerful initiator of apoptosis (Guven et al., 2014; Zhang et al., 2016), however, the mechanism by which hypoxia induces apoptosis in germ cells has yet to be defined. HIF- $1 \alpha$ may be a key factor in mediating apoptosis. In rat models, silencing the HIF- $1 \alpha$ gene in varicocele testes using the CRISPR/Cas9 gene editing technique significantly reduced the rate of apoptosis of spermatogenic cells and improved spermatogenic function by downregulating the VEGF/PI3K/AKT signaling pathway (Wang D. et al., 2020). Another study revealed that silencing HIF-1 $\alpha$ significantly downregulated the expression of Bax and cleaved caspase- 3 in the testes of varicocele rats (Zhao et al., 2019). In cell models, HIF- $1 \alpha$ induced GC- 2 cell apoptosis by activating the mitochondrial pathway and death receptor pathway under hypoxic conditions (Yin et al., 2018a). In addition, miR-210, a robust target of HIF-1 $\alpha$, also plays a crucial role in the apoptosis of germ cells (Lv et al., 2019). A study using a hypoxia workstation found that hypoxia induced miR-210 expression triggers apoptosis of mouse spermatocyte GC-2 cells by targeting Kruppel-like factor 7(KLF7), a transcription factor involved in cell proliferation (Gupta et al., 2020) (Figure 1).
Autophagy has been shown to play an important role in testicular damage under hypoxic conditions. In rats, varicocele testes cells showed increased expression of autophagy marker Beclin 1 and microtubule associated protein 1 light chain $3 \alpha$ (LC3) II/LC3I (Zhu et al., 2017); Exposure of GC-2 cells to hypoxia conditions reduced P62 protein expression and increased the expression of LC3 II and Beclin-1 (Yin et al., 2018b; Zhou et al., 2018). In varicocele rats, short-term hypoxia exposure promoted autophagy to stimulate testosterone secretion by degrading intracellular lipid droplets/total cholesterol. The change could be abolished by blocking autophagy (Ma et al., 2018) (Figure 1).

Notably, as a downstream target gene of HIF-1 $\alpha$, VEGF is upregulated under hypoxia, which is essential for endothelial growth and permeability (Apte et al., 2019). In addition to the well-known effects of VEGF, Korpelainen et al. observed that the VEGF transgene has non-endothelial target cells in the testis, leading to spermatogenic arrest and increased capillary density, which may regulate male fertility (Korpelainen et al., 1998). Another study reported that the VEGF upregulation in the testis under hypoxia suppresses the spermatogenesis by inhibiting germ cell proliferation, leading to aspermatogenesis and infertility (Nalbandian et al., 2003) (Figure 1).

\section{Systematic Inflammation}

Findings from several studies have linked increased levels of proinflammatory cytokines to spermatogenesis disorder, poor sperm quality and infertility (Zhao et al., 2017; Beigi Harchegani et al., 2020; Cao et al., 2020). Numerous studies have shown that hypoxia is a powerful cause of inflammation. In humans, exposure to intermittent hypoxia or acute hypoxia increased the serum levels of inflammatory markers, including interleukin 1 receptor antagonist (IL-1ra), interleukin 6 (IL-6) and C-reactive protein (CRP) (Hartmann et al., 2000; Gangwar et al., 2019). Other studies on obstructive sleep apnea syndrome suggested that patients with obstructive sleep apnea syndrome showed high 
serum levels of tumor necrosis factor- $\alpha$ (TNF- $\alpha$ ), IL-6, CRP, and spontaneous production of IL- 6 by monocytes compared with obese control subjects (Vgontzas et al., 2000; Yokoe et al., 2003). Hypoxia has also been shown to be positively correlated with these proinflammatory markers in animal studies (Ren and $\mathrm{Hu}$, 2017; Alshanwani et al., 2020).

Hypoxic exposure was suggested to promote the activity of numerous transcription factors, including nuclear factor- $\kappa \mathrm{B}(\mathrm{NF}-$ $\kappa \mathrm{B}$ ), a known target gene of HIF- $1 \alpha$ (Figure 3 ). NF- $\kappa \mathrm{B}$ is a heterodimer consisting of p50 and p65 subunits, which acts as a central transcriptional regulator of the immune response and immune cell function (Rius et al., 2008). Activation of NF$\kappa \mathrm{B}$ requires phosphorylation-induced proteasomal degradation of inhibitory $I \kappa \mathrm{B}$ proteins, which is mediated by $\mathrm{I} \kappa \mathrm{B}$ kinases

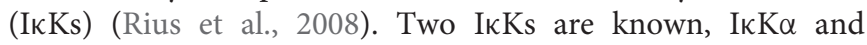
I $\kappa \mathrm{K} \beta$, in which I $\mathrm{K} \beta$ plays a major role in phosphorylation of I $\mathrm{B}$ inhibitors. Interestingly, the evidence showed that NF- $\kappa \mathrm{B}$ was activated in hypoxia through PHD-dependent hydroxylation of IKK- $\beta$ (Cummins et al., 2006) (Figure 3). Furthermore, findings in animals and humans found that hypoxia -induced inflammation is characterized by elevated levels of NF- $\kappa \mathrm{B}$ and the proinflammatory biomarkers IL-6, IL1, and TNF- $\alpha$ (Mazzeo, 2005; de Gonzalo-Calvo et al., 2010; S et al., 2012).

\section{Epigenetic Changes}

Epigenetic modifications, including histone modifications, DNA/RNA methylation and non-coding RNAs, affect the phenotype by regulating gene expression without altering the coding sequence of DNA. DNA methylation is one of the most pervasive epigenetic modification types and it remains stable during spermatogenesis (Liu Y. et al., 2019). Changing in sperm DNA methylation patterns are closely related to DNA fragmentation, reduced telomere length and male infertility (Khezri et al., 2019; Santana et al., 2019). A meta analytic study showed that the proportion of aberrant sperm DNA methylation in infertile men was 9.91 times higher than that in matched fertile men (Santi et al., 2017). Aberrant sperm DNA methylation was also found in asthenospermia or other types of male infertility (Kobayashi et al., 2007). Furthermore, reduced sperm concentration, motility and abnormal morphology were related to broad DNA hypermethylation across a number of loci (Rajender et al., 2011). Oxidative stress, an important pathological consequence of hypoxia, is a known stressor of DNA methylation (Niu et al., 2015), thus people or animals suffering from hypoxia have a higher risk of aberrant sperm DNA methylation. In this regard, Bahreinian et al. demonstrated a negative correlation between methylation and DNA fragmentation. They found that infertile men with varicocele showed lower DNA methylation as well as lower sperm parameters (sperm concentration, sperm motility, percentage abnormal morphology) and higher sperm DNA fragmentation compared with fertile men (Bahreinian et al., 2015). Interestingly, most of the differentially methylated CpG sites were hypomethylated in the varicocele group, and these regions show associations with male reproductive pathways such as semen quality, gamete generation, and meiotic and meiosis cell cycle based on gene ontology analysis (Santana et al., 2020) (Figure 4).

Notably, more powerful evidence is reflected in animal models. Wang et al. found that hypoxic treatment of F0 generation fish resulted in sperm DNA hypermethylation in the F0 and F2 generation, which was responsible for the aberrant sperm motility (Wang et al., 2016). Specifically, the exonic region of forkheadbox P2 (FOXP2), a conserved transcription factor involved in germ-cell development and spermatogenesis, was hypomethylated after hypoxic exposure (Figure 4).

Hypoxia can also affect male reproduction by regulating non-coding RNAs expression, including miR210. Mir210, also known as hypoxamiR, is a robust target of HIF and plays instrumental roles in hypoxic cell metabolism, survival, redox balance and angiogenesis (Cicchillitti et al., 2012). A study using hypoxic GC-2 cells showed that hypoxia increased miR210 expression triggered apoptosis of GC-2 cell via activation of the apoptosis signaling pathway (Lv et al., 2019). Another study found that miR-210 was negatively correlated with the sperm count and seminal inhibin-B expression and may be an invasive biomarker of Sertoli cell damage in varicocoele (Ma et al., 2021). In addition, findings from 25 infertile patients with varicocele and 14 fertile men found that hypoxia related lncRNAs, including MLLT4-AS1 and MIR210HG, showed significantly negative correlations with sperm count and sperm motility (Ata-Abadi et al., 2020) (Figure 4).

\section{HYPOXIC FACTORS CAUSING MALE INFERTILITY}

\section{Environmental Factors}

The Earth's surface is surrounded by a layer of air approximately $200 \mathrm{~km}$ thick, called the atmosphere. The atmosphere is a mixture of various gases, of which $\mathrm{O}_{2}$ accounts for $21 \%, \mathrm{CO}_{2}$ accounts for $0.027 \%$, and $\mathrm{N}_{2}$ accounts for $78 \%$, and these proportions remain balanced regardless of altitude. Dalton's law establishes that in any given combination of gases, the total pressure is equal to the sum of the partial pressures of the gases in the mixture, so the partial pressure of oxygen $\left(\mathrm{PO}_{2}\right)$ depends largely on the atmospheric pressure. At sea level, atmospheric pressure is about $100 \mathrm{Kpa}$. According to the Dalton's Law, the $\mathrm{PO}_{2}$ can be calculated as follows:

$$
\mathrm{AtmPO}_{2}=0.21^{*} 100 \mathrm{Kpa}=21 \mathrm{Kpa}
$$

Within the atmosphere, atmospheric pressure decreases with altitude, as does the $\mathrm{PO}_{2}$ (Figure 5). As the altitude increases, the partial pressure of inhaled oxygen decreases and hence the driving pressure of pulmonary gas exchange. Since atmospheric pressure is the sum of the partial pressure of the constituent gases, oxygen and nitrogen, and the partial pressure of water vapor (6.3 $\mathrm{kpa}$ at $\left.37^{\circ} \mathrm{C}\right)$. Thus the partial pressure of inspired oxygen $\left(\mathrm{PiO}_{2}\right)$ at sea level can be calculated as follows:

$$
\mathrm{PiO}_{2}=0.21^{*}(100 \mathrm{Kpa}-6.3 \mathrm{Kpa})=19.6 \mathrm{Kpa} .
$$




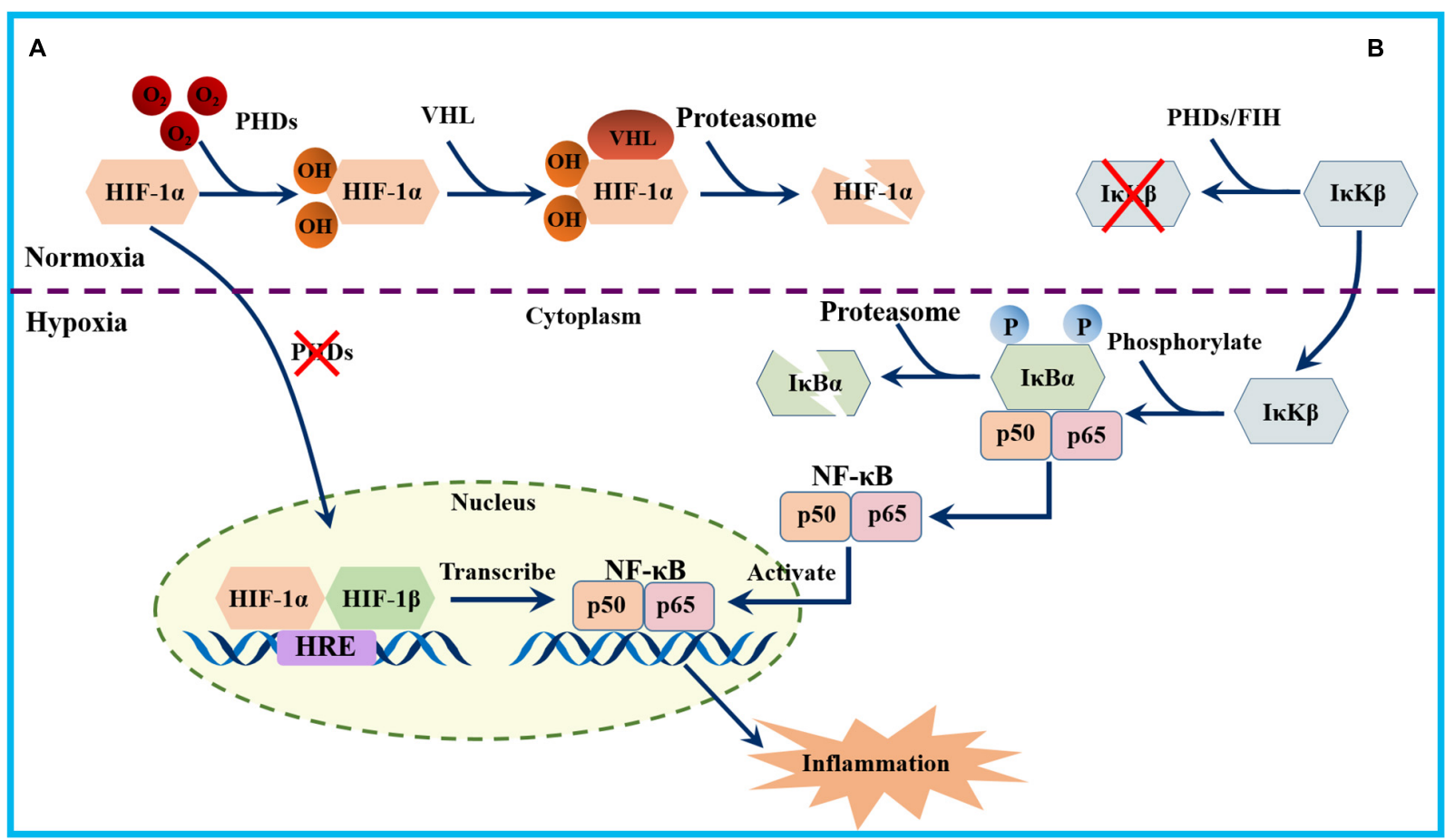

FIGURE 3 | Schematic diagram of the NF-kB activation pathways. (A) Under hypoxia, HIF-1 $\alpha$ is stabilized and translocate to the nucleus, dimerizing with the $\beta$ subunit and binds to HREs in the promoters of NF-kB to initiate its transcription. (B) Under normoxia, PHDs and factor inhibiting hypoxia-inducible factor (FIH)

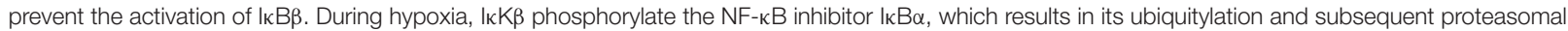
degradation. Dissociation of $\mathrm{I} B \alpha$ allows the nuclear translocation of the NF-kB heterodimer and the transcription of its target genes.

The partial pressure of inspired oxygen is reduced to about $13.3 \mathrm{kpa}$ at $3000 \mathrm{~m}$ altitude, at this inspired oxygen pressure, the alveolar oxygen pressure is about $8 \mathrm{kPa}$ (Peacock, 1998). At an altitude of $5500 \mathrm{~m}$, the $\mathrm{PO}_{2}$ and $\mathrm{PiO}_{2}$ directly drop to $50 \%$ of the sea level, and to $30 \%$ at $8900 \mathrm{~m}$ (Peacock, 1998; Grocott et al., 2009) $\mathrm{PaO}_{2}$ dropped from $100 \mathrm{mmHg}$ to $50 \mathrm{mmHg}$ at $5300 \mathrm{~m}$ and to $24.6 \mathrm{mmHg}$ at $8400 \mathrm{~m}$ (Grocott et al., 2009). $\mathrm{SaO}_{2}$ showed a decreased from 98 to $88 \%$ compared to the sea level (Bian et al., 2013).

As early as 1945 , Dr. Monge found that reproduction rates among European soldiers in the Andean highlands decreased significantly, which led him to propose that hypoxia reduces fertility (Monge, 1945). In a follow-up study, He et al. found that male soldiers exposure to hypoxia at high altitude $(5380 \mathrm{~m})$ for 6 months causes a significantly reduction in total sperm count, sperm density, motility, survival rate and a significant prolongation of liquefaction time in young male soldiers. 12 months after hypoxic exposure, total sperm count and sperm density increased, whereas sperm motility, survival rate, and the liquefaction time further decreased. Sperm velocities, progression ratios, and lateral head displacements were also decreased ( $\mathrm{He}$ et al., 2015). Another study of the mountain trekkers showed that 26 days of exposure at an altitude of $2000 \mathrm{~m}-5600 \mathrm{~m}$ resulted in lower sperm counts. Sperm motility showed no reduction immediately after returning to sea level, but decreased significantly after 1 month. Mature, normal and motile sperm in the ejaculate decreased immediately after returning to sea level and then again after 1 month (Verratti et al., 2008). Other studies involving workers, mountaineers, volunteers and border also showed significant decreases in semen quality (sperm density, motility, morphology, survival rate) after high altitude hypoxic exposure (Okumura et al., 2003; Verratti et al., 2008; He et al., 2015; Verratti et al., 2016). In addition, high altitude hypoxia also causes disorders in reproductive hormones, such as GnRH, LH, FSH, PRL and testosterone. A Finding from high altitude hypoxic male adults showed that serum levels of LH, PRL and testosterone were significantly decreased after 6 months of exposure (He et al., 2015). Another study of high altitude mountaineers revealed slightly decreased testosterone in the blood after 1 month of hypoxic exposure, which had decreased still further after 3 months (Okumura et al., 2003).

In animal models, male mice were exposed to simulated continuous or intermittent hypoxia of $4,200 \mathrm{~m}$ in a chamber for 33.2 days. Reproductive parameters analysis showed that there were decreased sperm count and increased teratozoospermia, sperm DNA fragmentation and the instability of DNA after hypoxic exposure (Vargas et al., 2011). Several hypoxia studies in rats exposed to high altitude have shown decreased semen parameters, reduced testis weight, degeneration of the germinal epithelium, sloughing of germ cells and Leydig cells, impairment of spermatogenesis and steroidogenesis (Gosney, 1984; Biswas et al., 1985; Gasco et al., 2003; Farias et al., 2005, 2008; Grocott et al., 2009). Similar phenotypes pertaining to other animals such 


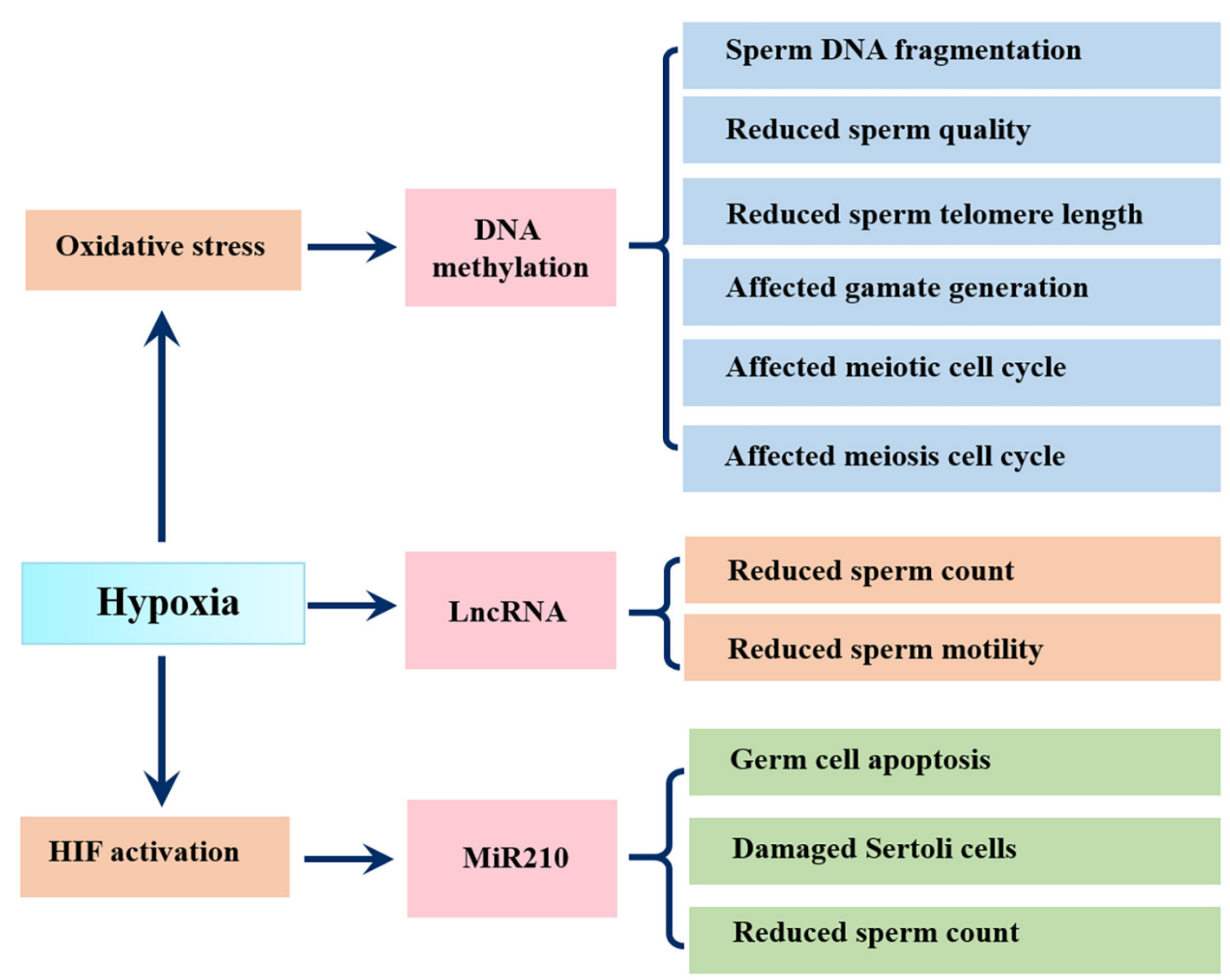

FIGURE 4 | Influence of hypoxia on epigenetic changes in sperm. Hypoxia causes oxidative stress, which changes DNA methylation in sperm, resulting in sperm DNA fragmentation, reduced sperm quality, sperm telomere length and affected gamate generation and affected meiotic and meiosis cell cycle; Hypoxia related IncRNAs show negative correlations with sperm count and sperm motility; Hypoxia activates miR210, leading to germ cell apoptosis, Sertoli cell damage and reduced sperm count.

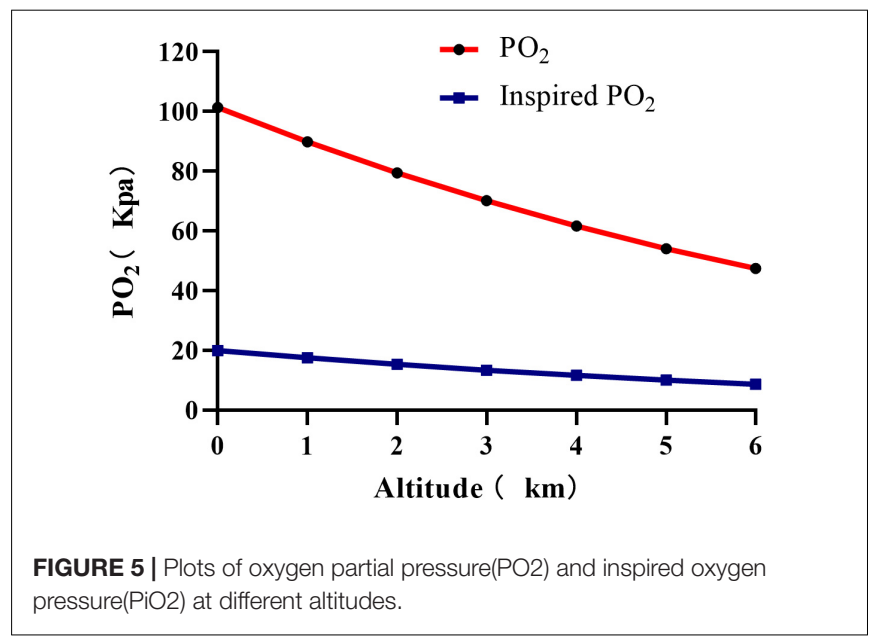

as ram (Cofre et al., 2018), toad (Biswas et al., 1985) and rhesus monkeys (Saxena, 1995), have also been reported. (A summary of the studies in the last 20 years is shown in Table $\mathbf{1})$.

\section{Pathological Factors Varicocele}

Testicular varicocele is a kind of vascular disease that refers to the abnormal expansion, elongation and tortuousness of the variegated venous plexus within the spermatic cord. During the occurrence of varicocele, the blood flow system of the testicular spermatic vein is damaged, leading to venous blood stasis, which increases the hydrostatic pressure in the testis and exceeds the microcirculation pressure of the testicular artery, resulting in testicular hypoxia (Gat et al., 2010a).Approximately 15\% of men worldwide have varicocele (Thomason and Fariss, 1979), and $19 \%-41 \%$ of them show primary infertility and $45 \%-81 \%$ show secondary infertility (Jarow et al., 1996). More than 50 years of studies have found that varicocele has a negative impact on sperm parameters, semen function, reproductive endocrine factors and testicular function in men.

Hypoxia is one of the most pathological processes of varicocele (Gat et al., 2010b). In patients with varicocele, testicular venous blood flow is blocked, resulting in a local hypoxia. This process is accompanied by the accumulation of HIF- $1 \alpha$ (Zhang et al., 2016; Goren et al., 2017). A study involving 
TABLE 1 | Summary of the studies reporting the reproductive consequences of high altitude.

\begin{tabular}{|c|c|c|c|}
\hline Altitude & Subjects & Reproductive consequences & References \\
\hline $7821 \mathrm{~m}$ & Human & $\begin{array}{l}\text { Decreased sperm count; increased abnormally shaped sperm; decreased testosterone } \\
\text { levels }\end{array}$ & Okumura et al., 2003 \\
\hline $4340 \mathrm{~m}$ & Rat & Decreased epididymal sperm count; disorder of spermatogenesis & Gasco et al., 2003 \\
\hline $4340 \mathrm{~m}$ & Rat & $\begin{array}{l}\text { Reduced spermiation (stage VIII) to half and the onset of spermatogenesis (stages IX-XI) to } \\
\text { a quarter; decreased sperm count }\end{array}$ & Gonzales et al., 2004 \\
\hline $3400 \mathrm{~m}$ & Rat & $\begin{array}{l}\text { Decreased epididymal spermatozoa count; reduced diameter of the seminiferous tubule } \\
\text { and the height of the spermatogenic epithelium }\end{array}$ & Cikutovic et al., 2009 \\
\hline $5000 \mathrm{~m}$ & Rat & $\begin{array}{l}\text { Decrease of cellularity of seminiferous epithelium; degeneration and sloughing of } \\
\text { seminiferous epithelial cells occasionally. }\end{array}$ & Liao et al., 2010 \\
\hline $5300 \mathrm{~m}$ & Human & Decreased sperm mtDNA copy numbers; lower nuclear DNA integrity & Luo et al., 2011 \\
\hline $5900 \mathrm{~m}$ & Human & Reduced sperm concentration & Pelliccione et al., 2011 \\
\hline $4200 \mathrm{~m}$ & Mouse & Testicular damage & Vargas et al., 2011 \\
\hline $5380 \mathrm{~m}$ & Human & Decreased sperm parameters; decreased LH, PRL and testosterone levels & He et al., 2015 \\
\hline $3600 \mathrm{~m}$ & Ram & Decreased sperm concentration, progressive motility and viability & Cofre et al., 2018 \\
\hline $3600 \mathrm{~m}$ & Human & $\begin{array}{l}\text { Decreased sperm concentration; increased the occurrence and frequency of sperm with } \\
\text { excessive head size, neck crimp, and tailless }\end{array}$ & Zheng et al., 2019 \\
\hline $5500 \mathrm{~m}$ & Rat & $\begin{array}{l}\text { Decreased sperm count and motility; increased sperm deformity rate; decreased } \\
\text { testosterone levels }\end{array}$ & Liu et al., 2020 \\
\hline
\end{tabular}

TABLE 2 | Summary of the studies reporting the reproductive consequence of varicocele.

\begin{tabular}{|c|c|c|}
\hline Subjects & Reproductive consequences & References \\
\hline Human & Poorer semen quality; higher serum levels of FSH; lower inhibin B; higher levels of LH & Damsgaard et al., 2016 \\
\hline Human & Sperm DNA damage & Ni et al., 2016 \\
\hline Human & Smaller testis; higher frequency of abnormal epididymis & Zhang et al., 2017 \\
\hline Human & A reduction in the concentration $/ \mathrm{mL}$ and the total sperm number & Pallotti et al., 2018 \\
\hline Human & Lower sperm production and motility; increased percentage of abnormal sperm morphology & $\begin{array}{l}\text { Oliva and Multigner, } \\
2018\end{array}$ \\
\hline Rat & lower sperm count and survival rate; disordered seminiferous epithelium & Zhao et al., 2019 \\
\hline Human & $\begin{array}{l}\text { Lower sperm parameters, sperm and leukocyte telomere length; higher DNA fragmentation, protamine deficiency, } \\
\text { and lipid peroxidation }\end{array}$ & Tahamtan et al., 2019 \\
\hline Human & Higher sperm DNA fragmentation index & Nguyen et al., 2019 \\
\hline Human & Lower total and total motile sperm counts; slightly higher testosterone levels & Redmon et al., 2019 \\
\hline Human & Non-obstructive azoospermia & Kavoussi et al., 2019 \\
\hline Human & Decreased sperm quality & Santana et al., 2020 \\
\hline Human & $\begin{array}{l}\text { Higher DNA fragmentation index; decreased all semen characteristics; an abnormality of at least one of the } \\
\text { spermatic parameters }\end{array}$ & Jellad et al., 2021 \\
\hline Human & Higher sperm DNA fragmentation and apoptosis rate & Ammar et al., 2021 \\
\hline Human & Reduced semen parameters; increased sperm DNA fragmentation & Finelli et al., 2021 \\
\hline Human & $\begin{array}{l}\text { Lower sperm concentration, motility and total sperm count;higher serum FSH levels, and higher seminal } \\
\text { oxidation-reduction potential and sperm DNA fragmentation index }\end{array}$ & Tanaka et al., 2020 \\
\hline
\end{tabular}

20 infertile men with varicocele and 20 fertile men showed that the sperm concentration, motility, morphology and sperm DNA integrity of varicocele men were significantly lower than those of fertile men, and molecular markers associated with the hypoxia pathway were significantly higher than those associated with the inflammation pathway, suggesting that hypoxia may be the main cause of infertility (Ghandehari-Alavijeh et al., 2019). Subsequent studies showed that hypoxia-related lncRNA expression is significantly elevated in semen from varicocele patients (Ata-Abadi et al., 2020). Mechanistically, oxidative and heat stress caused by hypoxia or hypoxia-ischemia and HIF$1 \alpha$ mediated germ cell apoptosis or sperm damage may be the main reasons (Zhang et al., 2016; Goren et al., 2017;
Zhu et al., 2017; Samanta et al., 2018; Zhao et al., 2019). (A summary of the studies in the last 5 years is shown in Table 2).

\section{Chronic Lung Diseases}

Chronic lung disease, such as chronic obstructive pulmonary disease(COPD), interstitial lung disease, asthma, emphysema, lung cancer and sleep apnea, can reduce ventilation-perfusion which may lead to clinically relevant hypoxemia. Hypoxemia can disturb the functions of the hypoventilation-pituitarygonadal axis, resulting in sex hormone suppression and sexual dysfunction (Semple et al., 1981; Semple P. A. et al., 1984; Semple P. D. et al., 1984). 
TABLE 3 | Summary of the studies reporting the reproductive consequences of chronic lung diseases.

\begin{tabular}{|c|c|c|c|}
\hline Types of diseases & Subjects & Reproductive consequences & References \\
\hline COPD & Human & Hypogonadism & Van Vliet et al., 2005 \\
\hline COPD & Human & Hypogonadism & Laghi et al., 2005 \\
\hline COPD & Human & Erectile dysfunction & Karadag et al., 2007 \\
\hline Pulmonary obstruction & Human & Reduced total and free testosterone levels & Svartberg et al., 2007 \\
\hline COPD & Human & Lower testosterone levels & Akbas et al., 2010 \\
\hline COPD & Human & Sexual dysfunctions & Collins et al., 2012 \\
\hline COPD & Human & Hypogonadism & $\begin{array}{l}\text { Balasubramanian and } \\
\text { Naing, } 2012\end{array}$ \\
\hline COPD & Human & Lower testosterone levels & Atlantis et al., 2013 \\
\hline COPD & Human & Significant reduction in total and free testosterone levels & Karakou et al., 2013 \\
\hline COPD & Rat & Decreased testosterone levels & Wang et al., 2019 \\
\hline COPD & Human & Serum testosterone depression & Rubinsztajn et al., 2019 \\
\hline Pulmonary emphysema & Mesocricetus auratus & $\begin{array}{l}\text { Decreased sperm quality; increased abnormal seminiferous tubules; decreased } \\
\text { seminiferous epithelium height; decreased sertoli cells; increased unclear } \\
\text { volume of leydig cells }\end{array}$ & Vieira et al., 2020 \\
\hline
\end{tabular}

TABLE 4 | Summary of the studies reporting the reproductive consequence of sleep apnea.

\begin{tabular}{|c|c|c|}
\hline Subjects & $\begin{array}{l}\text { Reproductive } \\
\text { consequences }\end{array}$ & References \\
\hline Human & $\begin{array}{l}\text { Reduced testosterone } \\
\text { levels }\end{array}$ & Gambineri et al., 2003 \\
\hline Human & $\begin{array}{l}\text { Decrease in erectile } \\
\text { function }\end{array}$ & Margel et al., 2004 \\
\hline Human & $\begin{array}{l}\text { Erection problems; } \\
\text { decreased overall sexual } \\
\text { satisfaction }\end{array}$ & Stannek et al., 2009 \\
\hline Human & Erectile dysfunction & Budweiser et al., 2009 \\
\hline Human & $\begin{array}{l}\text { Erectile dysfunction; low } \\
\text { testosterone levels }\end{array}$ & Andersen et al., 2010 \\
\hline Human & $\begin{array}{l}\text { Reduced free testosterone } \\
\text { and sexual quality }\end{array}$ & Hammoud et al., 2011 \\
\hline Mouse & $\begin{array}{l}\text { Decreased testosterone } \\
\text { levels }\end{array}$ & Wang et al., 2019 \\
\hline Mouse & $\begin{array}{l}\text { Reduced progressive } \\
\text { sperm motility; } \\
\text { downregulate fertility rate } \\
\text { and fetuses number }\end{array}$ & Torres et al., 2014 \\
\hline Rat & $\begin{array}{l}\text { Reduced sperm count and } \\
\text { sperm motility; impaired } \\
\text { spermatogenesis }\end{array}$ & Wang J. et al., 2020 \\
\hline Human & Higher infertility rate & Chen et al., 2021 \\
\hline
\end{tabular}

An autopsy study involving 10 men with hypoxia associated with bronchitis and emphysema lasting at least 15 years found that the total volume of Leydig cells in testis was significantly less than the volume in the matched control group. This atrophy may be a consequence of hypoxic inhibition of pituitary synthesis or the release of LH (Gosney, 1987). Another epidemiological study of 35 patients (24 males, 11 females) with primary bronchiectasis and 71 patients (54 males, 17 females) with secondary bronchiectasis showed a strong association between primary bronchiectasis and male infertility (Charpin et al., 1985). Other studies also demonstrated that testosterone deficiency is common in patients with COPD (Baillargeon et al., 2019). (A summary of the studies in the last 20 years is shown in Table 3).

\section{Obstructive Sleep Apnea Syndrome}

Obstructive sleep apnea syndrome (OSAS) is a common clinical condition that is characterized by recurrent closure of the upper airway during sleep (Levy et al., 2015). Chronic intermittent hypoxia is a hallmark of OSAS, and is an important pathogenic factor for male infertility (Kiernan et al., 2016). One study looking at the effects of obstructive sleep apnea on male sexual function investigated 24 men referred for sleep research. Significantly reduced serum testosterone levels were documented in 15 men with obstructive sleep apnea (34.5 apneas/h) and 9 non-obstructive sleep apnea snorers $(<5$ apneas $/ \mathrm{h})$, and this decrease was associated with lower $\min \mathrm{SaO}_{2}$ but not with other demographic, respiratory or sleep parameters (Santamaria et al., 1988). In another study with 5 OSA patients and 5 healthy middle-aged controls, Luboshitzky et al. found that patients with OSA had significantly higher $\mathrm{PaO}_{2}<90 \%$ values compared with the control groups. As expected, OSA patients had significantly lower testosterone values than in matched controls (Luboshitzky et al., 2005). In addition, a prospective cross-sectional analysis of 401 OSA patients showed that erectile dysfunction was found in $69 \%$ of patients with OSA. Stepwise multiple regression analysis revealed that mean $\mathrm{SaO}_{2}$ was independently associated with erectile dysfunction (Budweiser et al., 2009). Another study investigating the correlation between OSAS and erectile dysfunction showed that the prevalence of erectile dysfunction in patients with OSAS (19 of $32,59.3 \%$ ) was significantly higher than in the matched control group (8 of 27, 29.6\%). Erectile dysfunction was significantly associated with the lowest oxygen saturation decreased but not apnea-hypopnea index (Shin et al., 2008).

In animal models, male mice were subjected to chronic intermittent hypoxia $\left(20 \mathrm{~s}\right.$ at $5 \% \mathrm{O}_{2}$ followed by $40 \mathrm{~s}$ of room air, $6 \mathrm{~h}$ /day) in a gas controlled box with a frequency equivalent to sixty apneas per hour to simulate severe OSA. As expected, the male mice treated with OSA model experienced 
TABLE 5 | Summary of the studies reporting the reproductive consequences of hematological diseases.

\begin{tabular}{|c|c|c|c|}
\hline Types of diseases & Subjects & Reproductive consequences & References \\
\hline Sickle cell disease & Human & Priapism & Adeyoju et al., 2002 \\
\hline Sickle cell disease & Human & Priapism or erectile dysfunction & Madu et al., 2014 \\
\hline Sickle cell disease & Human & Lower testicular volume; shorter penis length & Martins et al., 2015 \\
\hline Sickle cell disease & Human & Impaired sperm parameters & Joseph et al., 2021 \\
\hline Sickle cell disease & Human & Repeated testicular infarction & Li et al., 2003 \\
\hline Sickle cell disease & Human & Decreased semen parameters & $\begin{array}{l}\text { Berthaut et al., } \\
2008\end{array}$ \\
\hline Thalassemia & Human & $\begin{array}{l}\text { Lower total sperm count, sperm motility and percent normal sperm morphology; lower serum LH, } \\
\text { FSH and testosterone levels }\end{array}$ & Safarinejad, 2008b \\
\hline Sickle cell disease & Human & Hypogonadism & $\begin{array}{l}\text { Taddesse et al., } \\
2012\end{array}$ \\
\hline Sickle cell disease & Human & Hypogonadism & $\begin{array}{l}\text { Morrison et al., } \\
2013\end{array}$ \\
\hline Thalassemia & Human & Increased sperm DNA damage; reduced sperm motility & Perera et al., 2002 \\
\hline Hemolytic anemia & Mouse & $\begin{array}{l}\text { Reduced sperm count, sperm natural morphology, sperm motility and viability and serum } \\
\text { testosterone concentration, increased DNA injury }\end{array}$ & $\begin{array}{l}\text { Mozafari et al., } \\
2016\end{array}$ \\
\hline Thalassemia & Human & Lower testis values; lower sperm concentrations and abnormal morphology & Chen et al., 2018 \\
\hline Hemolytic anemia & Mouse & $\begin{array}{l}\text { Testicular tubular atrophy and edema in the interstitial tissue; decreased sperm count, diminished } \\
\text { sperm motility and viability, diminished fertilizing potential }\end{array}$ & Anbara et al., 2018 \\
\hline
\end{tabular}

cyclic changes in $\mathrm{SaO}_{2}$ ranging from maxima of $95.4 \pm 0.1 \%$ (similar to baseline values) to minima of $62.3 \pm 3.5 \%(P<0.001)$, After 60 days of treatment, Torres et al. found that chronic intermittent hypoxia significantly decreased progressive sperm motility, the proportion of pregnant females and the number of fetuses per mating. Testicular oxidative stress levels were also increased compared with those of normoxic controls (Torres et al., 2014). In rats, Wang et al. found that male rats treated with obstructive sleep apnea hypopnea syndrome model (20$21 \% \mathrm{O}_{2}$ to $6-7 \% \mathrm{O}_{2}$ for $30 \mathrm{~s} ; 6-7 \% \mathrm{O}_{2}$ to $20-21 \% \mathrm{O}_{2}$ within $20 \mathrm{~s} ; 20-21 \% \mathrm{O}_{2}$ for $60 \mathrm{~s}, 8 \mathrm{~h} /$ day, 6 weeks) showed a decreased total sperm count and sperm motility and more structurally abnormal spermatogenic tubules (Wang J. et al., 2020). Thinned, arranged unevenly and atrophied spermatogenic tubules lumen, and the increased gap between the tubules was also observed in the obstructive sleep apnea hypopnea syndrome group (Wang J. et al., 2020).(A summary of the studies in the last 20 years is shown in Table 4).

\section{Hematological Diseases}

In humans, oxygen is exchanged in the alveoli of the lungs. More than $95 \%$ of oxygen is delivered into the capillary vessels via the alveolar-capillary exchange system and binds to hemoglobin. The heart pumps oxygenated blood to the periphery, which is crucial for organs and cells to function and perform oxidative phosphorylation. Cardiovascular and hematological disorders can cause a decrease in blood oxygen carrying capacity or blood circulation capacity, resulting in hypoxia (Joseph et al., 2021).

Sickle cell disease (SCD) is one of the most common, inherited hematological diseases caused by a single amino acid substitution (GTG for GAG) in the gene encoding hemoglobin $\beta$ (Papageorgiou et al., 2018). This substitution results in an abnormal oxygen-carrying protein, called sickle hemoglobin. Abnormal polymerization of sickle hemoglobin is responsible for vasoocclusion of testicular blood vessels, which affects oxygen delivery to the tissues and causes tissue hypoxia. A crosssectional study of 34 male patients with sick cell disease showed that 8 men (24\%) developed hypogonadal disease, characterized by decreased levels of testosterone, FSH and LH (Taddesse et al., 2012). Similar details have been found in the clinical laboratory (Dada and Nduka, 1980). Interestingly, a case report indicated that sickle cell disease caused repeat testicular infarction ( $\mathrm{Li}$ et al., 2003). In addition, several studies have reported that hypogonadism and poor sperm parameters including low sperm counts, impaired motility of spermatozoa and increased abnormal sperm morphology occur frequently in male patients with sickle cell disease (Nahoum et al., 1980; Osegbe et al., 1981; Grigg, 2007; Berthaut et al., 2008; Joseph et al., 2021). Surprisingly, priapism and impotence occur frequently in patients with SCD, with an incidence up to 50\% (Emond et al., 1980; Adeyoju et al., 2002; Nolan et al., 2005; Madu et al., 2014; Salonia et al., 2014; Chinegwundoh et al., 2017, 2020).

Beta-thalassemia is a hereditary blood disorder caused by reduced $(\beta+)$ or absent $(\beta 0)$ synthesis of the $\beta$-globin chains of hemoglobin. The variation in hemoglobin results in a reduction in oxygen affinity and oxygen carrying capacity, resulting in tissue hypoxia (Machogu and Machado, 2018). A study involving 168 men aged 18 years or older with homozygous beta-thalassemia and 84 healthy age matched male volunteers showed that the incidence of hypogonadotropic hypogonadism was as high as 76\% (128 men). Total sperm count, sperm motility, abnormal sperm morphology and serum LH, FSH, and T were lower in patients homozygous for beta-thalassemia than in normal controls (Safarinejad, 2008b). Furthermore, thalassemic patients had more sperm DNA damage than the controls (Perera et al., 2002; Elsedfy et al., 2018).(A summary of the studies in the last 20 years is shown in Table 5 ). 


\section{CONCLUDING REMARKS}

In this review, the available evidence clearly indicates that hypoxia, both environmental and pathological, has deleterious effects on sperm parameters, testicular function, reproductive hormone secretion and pregnancy outcomes for males. Excessive ROS mediated oxidative stress, HIF- $1 \alpha$ mediated germ cell apoptosis and proliferation inhibition, systematic inflammation and epigenetic changes seemed to be the central mechanisms. Given that infertility has become a global problem affecting human development, it is necessary to further study the molecular mechanism of infertility and search for molecular targets to reduce the burden of disease. Demonstration of the causal association between hypoxia and male infertility will provide more options for the treatment of male infertility.

\section{REFERENCES}

Abel, M. H., Baker, P. J., Charlton, H. M., Monteiro, A., Verhoeven, G., De Gendt, K., et al. (2008). Spermatogenesis and sertoli cell activity in mice lacking sertoli cell receptors for follicle-stimulating hormone and androgen. Endocrinology 149, 3279-3285. doi: 10.1210/en.2008-0086

Adeyoju, A. B., Olujohungbe, A. B., Morris, J., Yardumian, A., Bareford, D., Akenova, A., et al. (2002). Priapism in sickle-cell disease; incidence, risk factors and complications - an international multicentre study. BJU Int. 90, 898-902.

Agarwal, A., Baskaran, S., Parekh, N., Cho, C. L., Henkel, R., Vij, S., et al. (2021). Male infertility. Lancet 397, 319-333.

Agarwal, A., Hamada, A., and Esteves, S. C. (2012). Insight into oxidative stress in varicocele-associated male infertility: part 1. Nat. Rev. Urol. 9, 678-690. doi: 10.1038/nrurol.2012.197

Agarwal, A., Parekh, N., Panner Selvam, M. K., Henkel, R., Shah, R., Homa, S. T., et al. (2019). Male Oxidative Stress Infertility (MOSI): proposed terminology and clinical practice guidelines for management of idiopathic male infertility. World J. Mens. Health 37, 296-312.

Agarwal, A., Prabakaran, S., and Allamaneni, S. (2006). What an andrologist/urologist should know about free radicals and why. Urology 67, 2-8. doi: 10.1016/j.urology.2005.07.012

Agbaraji, V. O., Scott, R. B., Leto, S., and Kingslow, L. W. (1988). Fertility studies in sickle cell disease: semen analysis in adult male patients. Int. J. Fertil. 33, 347-352.

Aitken, J., and Fisher, H. (1994). Reactive oxygen species generation and human spermatozoa: the balance of benefit and risk. Bioessays 16, 259-267. doi: 10 . 1002/bies.950160409

Aitken, R. J. (2017). Reactive oxygen species as mediators of sperm capacitation and pathological damage. Mol. Reprod. Dev. 84, 1039-1052. doi: 10.1002/mrd. 22871

Aitken, R. J., Findlay, J. K., Hutt, K. J., and Kerr, J. B. (2011). Apoptosis in the germ line. Reproduction 141, 139-150. doi: 10.1530/rep-10-0232

Akbas, T., Karakurt, S., Unluguzel, G., Celikel, T., and Akalin, S. (2010). The endocrinologic changes in critically ill chronic obstructive pulmonary disease patients. COPD 7, 240-247. doi: 10.3109/15412555.2010.496815

Akinla, O. (1972). Abnormal haemoglobins, and pregnancy. Nigerian Med. J. 2, $11-13$.

Alshanwani, A. R., Shaheen, S., Faddah, L. M., Alhusaini, A. M., Ali, H. M., Hasan, I., et al. (2020). Manipulation of Quercetin and Melatonin in the Down-Regulation of HIF-1alpha, HSP-70 and VEGF Pathways in Rat's Kidneys Induced by Hypoxic Stress. Dose Response 18:1559325820949797.

Ammar, O., Tekeya, O., Hannachi, I., Sallem, A., Haouas, Z., and Mehdi, M. (2021). Increased Sperm DNA Fragmentation in Infertile Men with Varicocele: relationship with apoptosis, seminal oxidative stress, and spermatic parameters. Reprod. Sci. 28, 909-919. doi: 10.1007/s43032-020-00311-6

Anbara, H., Shahrooz, R., Razi, M., Malekinejad, H., and Najafi, G. (2018). The effect of vitamin $\mathrm{C}$ on mice hemolytic anemia induced by phenylhydrazine: an animal model study using histological changes in testis, pre-implantation

\section{AUTHOR CONTRIBUTIONS}

ZL, SW, and CG wrote the manuscript. YHu, JL, and WW revised the manuscript. YC and QLi was responsible for searching the references. $\mathrm{BH}$, YHua, and $\mathrm{QLu}$ projected and edited the manuscript. YZ and YX reviewed the manuscript. All authors read and approved the final manuscript.

\section{FUNDING}

This work was supported by the National Natural Science Foundation of China (No. 81773037) and Key Laboratory of Extreme Environmental Medicine, Ministry of Education of China (PR-KL2020GY003).

embryo development, and biochemical changes. Iran. J. Basic Med. Sci. 21, 668-677.

Andersen, M. L., Santos-Silva, R., Bittencourt, L. R., and Tufik, S. (2010). Prevalence of erectile dysfunction complaints associated with sleep disturbances in Sao Paulo, Brazil: a population-based survey. Sleep Med. 11, 1019-1024. doi: 10.1016/j.sleep.2009.08.016

Apte, R. S., Chen, D. S., and Ferrara, N. (2019). VEGF in signaling and disease: beyond discovery and development. Cell 176, 1248-1264. doi: 10.1016/j.cell. 2019.01.021

Arenas-Rios, E., Rosado Garcia, A., Cortes-Barberena, E., Konigsberg, M., Arteaga-Silva, M., Rodriguez-Tobon, A., et al. (2016). Reactive oxygen species production and antioxidant enzyme activity during epididymal sperm maturation in Corynorhinus mexicanus bats. Reprod. Biol. 16, 78-86. doi: 10.1016/j.repbio.2016.01.001

Ata-Abadi, N. S., Mowla, S. J., Aboutalebi, F., Dormiani, K., Kiani-Esfahani, A., Tavalaee, M., et al. (2020). Hypoxia-related long noncoding RNAs are associated with varicocele-related male infertility. PLoS One 15:e0232357. doi: 10.1371/ journal.pone.0232357

Atlantis, E., Fahey, P., Cochrane, B., Wittert, G., and Smith, S. (2013). Endogenous testosterone level and testosterone supplementation therapy in chronic obstructive pulmonary disease (COPD): a systematic review and meta-analysis. BMJ Open 3:e003127. doi: 10.1136/bmjopen-2013-003127

Bahreinian, M., Tavalaee, M., Abbasi, H., Kiani-Esfahani, A., Shiravi, A. H., and Nasr-Esfahani, M. H. (2015). DNA hypomethylation predisposes sperm to DNA damage in individuals with varicocele. Syst. Biol. Reprod. Med. 61, 179-186. doi: 10.3109/19396368.2015.1020116

Bai, G., Yang, B., Tong, W., and Li, H. (2018). Hypobaric hypoxia causes impairment of spermatogenesis in developing rats at pre-puberty. Andrologia. doi: 10.1111/and.13000 [Epub ahead of print].

Baillargeon, J., Urban, R. J., Zhang, W., Zaiden, M. F., Javed, Z., Sheffield-Moore, M., et al. (2019). Testosterone replacement therapy and hospitalization rates in men with COPD. Chron. Respir. Dis. 16:1479972318793004.

Balasubramanian, V., and Naing, S. (2012). Hypogonadism in chronic obstructive pulmonary disease: incidence and effects. Curr. Opin. Pulm. Med. 18, 112-117. doi: $10.1097 / \mathrm{mcp} .0 \mathrm{~b} 013 \mathrm{e} 32834 \mathrm{feb} 37$

Beigi Harchegani, A., Dahan, H., Tahmasbpour, E., Bakhtiari Kaboutaraki, H., and Shahriary, A. (2020). Effects of zinc deficiency on impaired spermatogenesis and male infertility: the role of oxidative stress, inflammation and apoptosis. Hum. Fertil. 23, 5-16. doi: 10.1080/14647273.2018.1494390

Bejarano, I., Monllor, F., Marchena, A. M., Ortiz, A., Lozano, G., Jimenez, M. I., et al. (2014). Exogenous melatonin supplementation prevents oxidative stressevoked DNA damage in human spermatozoa. J. Pineal Res. 57, 333-339. doi: 10.1111/jpi.12172

Bekker, A., Holland, H. D., Wang, P. L., Rumble, D. III, Stein, H. J., Hannah, J. L., et al. (2004). Dating the rise of atmospheric oxygen. Nature 427, 117-120. doi: $10.1038 /$ nature 02260

Berthaut, I., Guignedoux, G., Kirsch-Noir, F., de Larouziere, V., Ravel, C., Bachir, D., et al. (2008). Influence of sickle cell disease and treatment with hydroxyurea 
on sperm parameters and fertility of human males. Haematologica 93, 988-993. doi: 10.3324/haematol.11515

Bian, S. Z., Zhang, J. H., Gao, X. B., Li, M., Yu, J., Liu, X., et al. (2013). Risk factors for high-altitude headache upon acute high-altitude exposure at 3700 $\mathrm{m}$ in young Chinese men: a cohort study. J. Headache Pain 14:35.

Biswas, H. M., Boral, M. C., and Ghosh, A. K. (1985). Effect of hypobaric hypoxia on spermatogenesis, Leydig cells and delta 5-3 beta-hydroxysteroid dehydrogenase activity in toad. Indian J. Physiol. Pharmacol. 29, 139-145.

Boksa, P., and Zhang, Y. (2008). Global birth hypoxia increases the neonatal testosterone surge in the rat. Neuroendocrinology 88, 266-275. doi: 10.1159/ 000142387

Bomhard, E. M., and Gelbke, H. P. (2013). Hypoxaemia affects male reproduction: a case study of how to differentiate between primary and secondary hypoxic testicular toxicity due to chemical exposure. Arch. Toxicol. 87, 1201-1218. doi: 10.1007/s00204-013-1024-6

Boveris, A., and Chance, B. (1973). The mitochondrial generation of hydrogen peroxide. General properties and effect of hyperbaric oxygen. Biochem. J. 134, 707-716. doi: 10.1042/bj1340707

Bremner, W. J., Millar, M. R., Sharpe, R. M., and Saunders, P. T. (1994). Immunohistochemical localization of androgen receptors in the rat testis: evidence for stage-dependent expression and regulation by androgens. Endocrinology 135, 1227-1234. doi: 10.1210/endo.135.3.8070367

Budweiser, S., Enderlein, S., Jorres, R. A., Hitzl, A. P., Wieland, W. F., Pfeifer, M., et al. (2009). Sleep apnea is an independent correlate of erectile and sexual dysfunction. J. Sex. Med. 6, 3147-3157. doi: 10.1111/j.1743-6109.2009.01372.x

Cao, Z., Huang, W., Sun, Y., and Li, Y. (2020). Deoxynivalenol induced spermatogenesis disorder by blood-testis barrier disruption associated with testosterone deficiency and inflammation in mice. Environ. Pollut. 264:114748. doi: 10.1016/j.envpol.2020.114748

Charpin, D., Ohayon, R., and Charpin, J. (1985). [Epidemiological approach to the relationship between bronchiectasis and sterility]. Rev. Mal. Respir. 2, 151-154.

Chen, H. C., Chung, C. H., and Chien, W. C. (2021). Association between deviated nasal septum with inferior turbinate hypertrophy and the risk of male infertility. Am. J. Rhinol. Allergy 35, 17-25. doi: 10.1177/1945892420932485

Chen, H., Zhou, L., Lin, C. Y., Beattie, M. C., Liu, J., and Zirkin, B. R. (2010). Effect of glutathione redox state on Leydig cell susceptibility to acute oxidative stress. Mol. Cell. Endocrinol. 323, 147-154. doi: 10.1016/j.mce.2010.0 2.034

Chen, M. J., Peng, S. S., Lu, M. Y., Yang, Y. L., Jou, S. T., Chang, H. H., et al. (2018). Effect of iron overload on impaired fertility in male patients with transfusiondependent beta-thalassemia. Pediatr. Res. 83, 655-661. doi: 10.1038/pr.2017. 296

Chen, W., Zhang, Z., Chang, C., Yang, Z., Wang, P., Fu, H., et al. (2020). A bioenergetic shift is required for spermatogonial differentiation. Cell Discov. $6: 56$.

Chinegwundoh, F. I., Smith, S., and Anie, K. A. (2017). Treatments for priapism in boys and men with sickle cell disease. Cochrane Database Syst. Rev. 9:CD004198.

Chinegwundoh, F. I., Smith, S., and Anie, K. A. (2020). Treatments for priapism in boys and men with sickle cell disease. Cochrane Database Syst. Rev. 4:CD004198.

Cho, Y. M., Chou, J. C., Fang, C. M., Hu, S., Wang, K. L., Wang, S. W., et al. (2019). Chronic intermittent hypoxia stimulates testosterone production in rat Leydig cells. Life Sci. 233:116694. doi: 10.1016/j.lfs.2019.116694

Choudhry, H., and Harris, A. L. (2018). Advances in Hypoxia-inducible factor biology. Cell Metab. 27, 281-298. doi: 10.1016/j.cmet.2017.10.005

Cicchillitti, L., Di Stefano, V., Isaia, E., Crimaldi, L., Fasanaro, P., Ambrosino, V., et al. (2012). Hypoxia-inducible factor 1-alpha induces miR-210 in normoxic differentiating myoblasts. J. Biol. Chem. 287, 44761-44771. doi: 10.1074/jbc. m112.421255

Cikutovic, M., Fuentes, N., and Bustos-Obregon, E. (2009). Effect of intermittent hypoxia on the reproduction of rats exposed to high altitude in the Chilean Altiplano. High Alt. Med. Biol. 10, 357-363. doi: 10.1089/ham.2009.1035

Cofre, E., Peralta, O. A., Raggi, A., De Los Reyes, M., Sales, F., Gonzalez-Bulnes, A., et al. (2018). Ram semen deterioration by short-term exposure to high altitude is prevented by improvement of antioxidant status. Animal 12, 1007-1014. doi: $10.1017 / \mathrm{s} 1751731117002452$
Collins, E. G., Halabi, S., Langston, M., Schnell, T., Tobin, M. J., and Laghi, F. (2012). Sexual dysfunction in men with COPD: impact on quality of life and survival. Lung 190, 545-556. doi: 10.1007/s00408-012-9398-4

Cross, B. A., and Silver, I. A. (1962). Neurovascular control of oxygen tension in the testis and epididymis. J. Reprod. Fertil. 3, 377-395. doi: 10.1530/jrf.0.0030377

Cummins, E. P., Berra, E., Comerford, K. M., Ginouves, A., Fitzgerald, K. T., Seeballuck, F., et al. (2006). Prolyl hydroxylase-1 negatively regulates IkappaB kinase-beta, giving insight into hypoxia-induced NFkappaB activity. Proc. Natl. Acad. Sci. U.S.A. 103, 18154-18159. doi: 10.1073/pnas.0602235103

Dada, O. A., and Nduka, E. U. (1980). Endocrine function and haemoglobinopathies: relation between the sickle cell gene and circulating plasma levels of testosterone, luteinising hormone (LH) and follicle stimulating hormone (FSH) in adult males. Clin. Chim. Acta 105, 269-273. doi: 10.1016/0009-8981(80)90469-6

Damsgaard, J., Joensen, U. N., Carlsen, E., Erenpreiss, J., Blomberg Jensen, M., Matulevicius, V., et al. (2016). Varicocele is associated with impaired semen quality and reproductive hormone levels: a study of 7035 healthy young men from six European countries. Eur. Urol. 70, 1019-1029. doi: 10.1016/j.eururo. 2016.06.044

de Gonzalo-Calvo, D., Neitzert, K., Fernandez, M., Vega-Naredo, I., Caballero, B., Garcia-Macia, M., et al. (2010). Differential inflammatory responses in aging and disease: TNF-alpha and IL-6 as possible biomarkers. Free Radic. Biol. Med. 49, 733-737. doi: 10.1016/j.freeradbiomed.2010.05.019

De Sanctis, V., Borsari, G., Brachi, S., Govoni, M., and Carandina, G. (2008). Spermatogenesis in young adult patients with beta-thalassaemia major longterm treated with desferrioxamine. Georgian Med. News 156, 74-77.

Donayre, J., Guerra-Garcia, R., Moncloa, F., and Sobrevilla, L. A. (1968). Endocrine studies at high altitude. IV. Changes in the semen of men. J. Reprod. Fertil. 16, 55-58. doi: 10.1530/jrf.0.0160055

Du Plessis, S. S., Agarwal, A., Halabi, J., and Tvrda, E. (2015). Contemporary evidence on the physiological role of reactive oxygen species in human sperm function. J. Assist. Reprod. Genet. 32, 509-520. doi: 10.1007/s10815-014-0425-7

el-Hazmi, M. A., Bahakim, H. M., and al-Fawaz, I. (1992). Endocrine functions in sickle cell anaemia patients. J. Trop. Pediatr. 38, 307-313. doi: 10.1093/tropej/ 38.6.307

Elsedfy, H., De Sanctis, V., Ahmed, A. Y., Mohamed, N. R., Arafa, M., and Elalfy, M. S. (2018). A pilot study on sperm DNA damage in beta-thalassemia major: Is there a role for antioxidants? Acta Biomed. 89, 47-54.

Emond, A. M., Holman, R., Hayes, R. J., and Serjeant, G. R. (1980). Priapism and impotence in homozygous sickle cell disease. Arch. Intern. Med. 140, 1434-1437. doi: 10.1001/archinte.140.11.1434

Farias, J. G., Bustos-Obregon, E., Orellana, R., Bucarey, J. L., Quiroz, E., and Reyes, J. G. (2005). Effects of chronic hypobaric hypoxia on testis histology and round spermatid oxidative metabolism. Andrologia 37, 47-52. doi: 10.1111/j.14390272.2004.00651.x

Farias, J. G., Bustos-Obregon, E., Tapia, P. J., Gutierrez, E., Zepeda, A., Juantok, C., et al. (2008). Time course of endocrine changes in the hypophysis-gonad axis induced by hypobaric hypoxia in male rats. J. Reprod. Dev. 54, 18-21. doi: 10.1262/jrd.19046

Finelli, R., Pallotti, F., Cargnelutti, F., Faja, F., Carlini, T., Rizzo, F., et al. (2021). Sperm DNA damage and cytokines in varicocele: a case-control study. Andrologia 53:e14023.

Ford, W. C. (2004). Regulation of sperm function by reactive oxygen species. Hum. Reprod. Update 10, 387-399. doi: 10.1093/humupd/dmh034

Fouchecourt, S., Livera, G., Messiaen, S., Fumel, B., Parent, A. S., Marine, J. C., et al. (2016). Apoptosis of Sertoli cells after conditional ablation of murine double minute $2(\mathrm{Mdm} 2)$ gene is p53-dependent and results in male sterility. Cell Death Differ. 23, 521-530. doi: 10.1038/cdd.2015.120

Friedman, G., Freeman, R., Bookchin, R., Boyar, R., Murthy, G., and Hellman, L. (1974). Testicular function in sickle cell disease. Fertil. Steril. 25, 1018-1021. doi: 10.1016/s0015-0282(16)40809-5

Gambineri, A., Pelusi, C., and Pasquali, R. (2003). Testosterone levels in obese male patients with obstructive sleep apnea syndrome: relation to oxygen desaturation, body weight, fat distribution and the metabolic parameters. J. Endocrinol. Invest. 26, 493-498. doi: 10.1007/bf03345209

Gangwar, A., Pooja, Sharma, M., Singh, K., Patyal, A., Bhaumik, G., et al. (2019). Intermittent normobaric hypoxia facilitates high altitude acclimatization by 
curtailing hypoxia-induced inflammation and dyslipidemia. Pflugers Arch. 471, 949-959. doi: 10.1007/s00424-019-02273-4

Gasco, M., Rubio, J., Chung, A., Villegas, L., and Gonzales, G. F. (2003). Effect of high altitude exposure on spermatogenesis and epididymal sperm count in male rats. Andrologia 35, 368-374. doi: 10.1111/j.1439-0272.2003.tb00874.x

Gat, Y., Gornish, M., Chakraborty, J., Perlow, A., Levinger, U., and Pasqualotto, F. (2010a). Azoospermia and maturation arrest: malfunction of valves in erect poster of humans leads to hypoxia in sperm production site. Andrologia 42, 389-394. doi: 10.1111/j.1439-0272.2010.01083.x

Gat, Y., Gornish, M., Navon, U., Chakraborty, J., Bachar, G. N., and BenShlomo, I. (2006). Right varicocele and hypoxia, crucial factors in male infertility: fluid mechanics analysis of the impaired testicular drainage system. Reprod. Biomed. Online 13, 510-515. doi: 10.1016/s1472-6483(10)6 0638-4

Gat, Y., Gornish, M., Perlow, A., Chakraborty, J., Levinger, U., Ben-Shlomo, I., et al. (2010b). Azoospermia and Sertoli-cell-only syndrome: hypoxia in the sperm production site due to impairment in venous drainage of male reproductive system. Andrologia 42, 314-321. doi: 10.1111/j.1439-0272.2010.01047.x

Gat, Y., Zukerman, Z., Chakraborty, J., and Gornish, M. (2005). Varicocele, hypoxia and male infertility. Fluid Mechanics analysis of the impaired testicular venous drainage system. Hum. Reprod. 20, 2614-2619. doi: 10.1093/humrep/dei089

Ghandehari-Alavijeh, R., Tavalaee, M., Zohrabi, D., Foroozan-Broojeni, S., Abbasi, H., and Nasr-Esfahani, M. H. (2019). Hypoxia pathway has more impact than inflammation pathway on etiology of infertile men with varicocele. Andrologia 51:e13189. doi: 10.1111/and.13189

Ghosh, S., and Mukherjee, S. (2018). Testicular germ cell apoptosis and sperm defects in mice upon long-term high fat diet feeding. J. Cell. Physiol. 233, 6896-6909. doi: $10.1002 /$ jcp. 26581

Gonzales, G. F. (2013). Serum testosterone levels and excessive erythrocytosis during the process of adaptation to high altitudes. Asian J. Androl. 15, 368-374. doi: $10.1038 /$ aja.2012.170

Gonzales, G. F., Gasco, M., Cordova, A., Chung, A., Rubio, J., and Villegas, L. (2004). Effect of Lepidium meyenii (Maca) on spermatogenesis in male rats acutely exposed to high altitude $(4340 \mathrm{~m})$. J. Endocrinol. 180, 87-95. doi: 10.1677/joe.0.1800087

Goren, M. R., Kilinc, F., Kayaselcuk, F., Ozer, C., Oguzulgen, I., and Hasirci, E. (2017). Effects of experimental left varicocele repair on hypoxiainducible factor-1alpha and vascular endothelial growth factor expressions and angiogenesis in rat testis. Andrologia 49:e12614. doi: 10.1111/and.12614

Gosney, J. R. (1984). Effects of hypobaric hypoxia on the Leydig cell population of the testis of the rat. J. Endocrinol. 103, 59-62. doi: 10.1677/joe.0.1030059

Gosney, J. R. (1987). Atrophy of Leydig cells in the testes of men with longstanding chronic bronchitis and emphysema. Thorax 42, 615-619. doi: 10.1136/thx.42. 8.615

Grigg, A. (2007). Effect of hydroxyurea on sperm count, motility and morphology in adult men with sickle cell or myeloproliferative disease. Intern. Med. J. 37, 190-192. doi: 10.1111/j.1445-5994.2006.01290.x

Griswold, M. D. (1998). The central role of Sertoli cells in spermatogenesis. Semin. Cell Dev. Biol. 9, 411-416. doi: 10.1006/scdb.1998.0203

Griswold, M. D. (2016). Spermatogenesis: the commitment to meiosis. Physiol. Rev. 96, 1-17. doi: 10.1152/physrev.00013.2015

Grocott, M. P., Martin, D. S., Levett, D. Z., McMorrow, R., Windsor, J., Montgomery, H. E., et al. (2009). Arterial blood gases and oxygen content in climbers on Mount Everest. N. Engl. J. Med. 360, 140-149. doi: 10.1056/ nejmoa0801581

Guo, W., Li, M., and Bhasin, S. (2014). Testosterone supplementation improves anemia in aging male mice. J. Gerontol. A Biol. Sci. Med. Sci. 69, 505-513. doi: 10.1093/gerona/glt127

Gupta, R., Malvi, P., Parajuli, K. R., Janostiak, R., Bugide, S., Cai, G., et al. (2020). KLF7 promotes pancreatic cancer growth and metastasis by up-regulating ISG expression and maintaining Golgi complex integrity. Proc. Natl. Acad. Sci. U.S.A. 117, 12341-12351. doi: 10.1073/pnas.2005156117

Guven, A., Ickin, M., Uzun, O., Bakar, C., Balbay, E. G., and Balbay, O. (2014). Erdosteine protects rat testis tissue from hypoxic injury by reducing apoptotic cell death. Andrologia 46, 50-58. doi: 10.1111/and.12041

Hammoud, A. O., Walker, J. M., Gibson, M., Cloward, T. V., Hunt, S. C., Kolotkin, R. L., et al. (2011). Sleep apnea, reproductive hormones and quality of sexual life in severely obese men. Obesity 19, 1118-1123. doi: 10.1038/oby.2010.344
Hartmann, G., Tschop, M., Fischer, R., Bidlingmaier, C., Riepl, R., Tschop, K., et al. (2000). High altitude increases circulating interleukin-6, interleukin-1 receptor antagonist and C-reactive protein. Cytokine 12, 246-252. doi: 10.1006/cyto. 1999.0533

Hatzimouratidis, K., Amar, E., Eardley, I., Giuliano, F., Hatzichristou, D., Montorsi, F., et al. (2010). Guidelines on male sexual dysfunction: erectile dysfunction and premature ejaculation. Eur. Urol. 57, 804-814. doi: 10.1016/j.eururo.2010.02. 020

He, J., Cui, J., Wang, R., Gao, L., Gao, X., Yang, L., et al. (2015). Exposure to Hypoxia at High Altitude $(5380 \mathrm{~m})$ for 1 Year Induces reversible effects on semen quality and serum reproductive hormone levels in young male adults. High Alt. Med. Biol. 16, 216-222. doi: 10.1089/ham.2014.1046

Hwang, G. S., Wang, S. W., Tseng, W. M., Yu, C. H., and Wang, P. S. (2007). Effect of hypoxia on the release of vascular endothelial growth factor and testosterone in mouse TM3 Leydig cells. Am. J. Physiol. Endocrinol. Metab. 292, E1763-E1769.

Jarow, J. P., Coburn, M., and Sigman, M. (1996). Incidence of varicoceles in men with primary and secondary infertility. Urology 47, 73-76. doi: 10.1016/s00904295(99)80385-9

Jellad, S., Hammami, F., Khalbous, A., Messousi, M., Khiari, R., Ghozzi, S., et al. (2021). Sperm DNA status in infertile patients with clinical varicocele. Prog. Urol. 31, 105-111. doi: 10.1016/j.purol.2020.07.241

Jensen, C. F. S., Ostergren, P., Dupree, J. M., Ohl, D. A., Sonksen, J., and Fode, M. (2017). Varicocele and male infertility. Nat. Rev. Urol. 14, 523-533.

Joseph, L., Jean, C., Manceau, S., Chalas, C., Arnaud, C., Kamdem, A., et al. (2021). Effect of hydroxyurea exposure before puberty on sperm parameters in males with sickle cell disease. Blood 137, 826-829. doi: 10.1182/blood.2020006270

Karadag, F., Ozcan, H., Karul, A. B., Ceylan, E., and Cildag, O. (2007). Correlates of erectile dysfunction in moderate-to-severe chronic obstructive pulmonary disease patients. Respirology 12, 248-253. doi: 10.1111/j.1440-1843.2006. 01042.x

Karakou, E., Glynos, C., Samara, K. D., Msaouel, P., Koutsilieris, M., and Vassilakopoulos, T. (2013). Profile of endocrinological derangements affecting PSA values in patients with COPD. In Vivo 27, 641-649.

Kastelic, J. P., Wilde, R. E., Bielli, A., Genovese, P., Rizzoto, G., and Thundathil, J. (2019). Hyperthermia is more important than hypoxia as a cause of disrupted spermatogenesis and abnormal sperm. Theriogenology 131, 177-181. doi: 10. 1016/j.theriogenology.2019.03.040

Kavoussi, P. K., Hunn, C., Gilkey, M. S., Chen, S. H., Kavoussi, K. M., Wininger, J. D., et al. (2019). Sertoli cell only syndrome induced by a varicocele. Transl. Androl. Urol. 8, 405-408.

Khezri, A., Narud, B., Stenseth, E. B., Johannisson, A., Myromslien, F. D., Gaustad, A. H., et al. (2019). DNA methylation patterns vary in boar sperm cells with different levels of DNA fragmentation. BMC Genomics 20:897. doi: 10.1186/ s12864-019-6307-8

Kiernan, E. A., Smith, S. M., Mitchell, G. S., and Watters, J. J. (2016). Mechanisms of microglial activation in models of inflammation and hypoxia: implications for chronic intermittent hypoxia. J. Physiol. 594, 1563-1577. doi: 10.1113/jp271502

Kim, J. W., Tchernyshyov, I., Semenza, G. L., and Dang, C. V. (2006). HIF-1mediated expression of pyruvate dehydrogenase kinase: a metabolic switch required for cellular adaptation to hypoxia. Cell Metab. 3, 177-185. doi: 10. 1016/j.cmet.2006.02.002

Kim, S. D., and Cho, K. S. (2019). Obstructive sleep apnea and testosterone deficiency. World J. Mens. Health 37, 12-18.

Kobayashi, H., Sato, A., Otsu, E., Hiura, H., Tomatsu, C., Utsunomiya, T., et al. (2007). Aberrant DNA methylation of imprinted loci in sperm from oligospermic patients. Hum. Mol. Genet. 16, 2542-2551. doi: 10.1093/hmg/ ddm 187

Korpelainen, E. I., Karkkainen, M. J., Tenhunen, A., Lakso, M., Rauvala, H., Vierula, M., et al. (1998). Overexpression of VEGF in testis and epididymis causes infertility in transgenic mice: evidence for nonendothelial targets for VEGF. J. Cell Biol. 143, 1705-1712. doi: 10.1083/jcb.143.6.1705

Laghi, F., Antonescu-Turcu, A., Collins, E., Segal, J., Tobin, D. E., Jubran, A., et al. (2005). Hypogonadism in men with chronic obstructive pulmonary disease: prevalence and quality of life. Am. J. Respir. Crit. Care Med. 171, 728-733. doi: 10.1164/rccm.200501-037oc

Lai, K. P., Li, J. W., Wang, S. Y., Wan, M. T., Chan, T. F., Lui, W. Y., et al. (2018). Transcriptomic analysis reveals transgenerational effect of hypoxia on 
the neural control of testicular functions. Aquat. Toxicol. 195, 41-48. doi: 10.1016/j.aquatox.2017.12.005

Lee, J. D., Jeng, S. Y., and Lee, T. H. (2006). Increased expression of hypoxiainducible factor-1alpha in the internal spermatic vein of patients with varicocele. J. Urol. 175, 1045-1048. doi: 10.1016/s0022-5347(05)00417-9

Levy, P., Kohler, M., McNicholas, W. T., Barbe, F., McEvoy, R. D., Somers, V. K., et al. (2015). Obstructive sleep apnoea syndrome. Nat. Rev. Dis. Primers 1:15015.

Li, M., Fogarty, J., Whitney, K. D., and Stone, P. (2003). Repeated testicular infarction in a patient with sickle cell disease: a possible mechanism for testicular failure. Urology 62:551. doi: 10.1016/s0090-4295(03)00482-5

Liang, M., Wen, J., Dong, Q., Zhao, L. G., and Shi, B. K. (2015). Testicular hypofunction caused by activating p53 expression induced by reactive oxygen species in varicocele rats. Andrologia 47, 1175-1182. doi: 10.1111/and.12400

Liao, W., Cai, M., Chen, J., Huang, J., Liu, F., Jiang, C., et al. (2010). Hypobaric hypoxia causes deleterious effects on spermatogenesis in rats. Reproduction 139, 1031-1038. doi: 10.1530/rep-09-0557

Lin, W. W., Lamb, D. J., Wheeler, T. M., Abrams, J., Lipshultz, L. I., and Kim, E. D. (1997). Apoptotic frequency is increased in spermatogenic maturation arrest and hypospermatogenic states. J. Urol. 158, 1791-1793. doi: 10.1016/s00225347(01)64130-2

Liu, B., Wu, S. D., Shen, L. J., Zhao, T. X., Wei, Y., Tang, X. L., et al. (2019). Spermatogenesis dysfunction induced by PM2.5 from automobile exhaust via the ROS-mediated MAPK signaling pathway. Ecotoxicol. Environ. Saf. 167, 161-168. doi: 10.1016/j.ecoenv.2018.09.118

Liu, P., Yu, S., Cui, Y., He, J., Zhang, Q., Sun, J., et al. (2018). Regulation by Hsp27/P53 in testis development and sperm apoptosis of male cattle (cattle-yak and yak). J. Cell. Physiol. 234, 650-660. doi: 10.1002/jcp.26822

Liu, T., Han, Y., Zhou, T., Zhang, R., Chen, H., Chen, S., et al. (2019). Mechanisms of ROS-induced mitochondria-dependent apoptosis underlying liquid storage of goat spermatozoa. Aging 11, 7880-7898. doi: 10.18632/aging.102295

Liu, X., Liu, S., and Xu, C. (2020). Effects of leptin on HPG axis and reproductive function in male rat in simulated altitude of $5500 \mathrm{~m}$ hypoxia environment. Biochem. Biophys. Res. Commun. 529, 104-111. doi: 10.1016/j.bbrc.2020.05.194

Liu, Y., Zhang, Y., Yin, J., Gao, Y., Li, Y., Bai, D., et al. (2019). Distinct H3K9me3 and DNA methylation modifications during mouse spermatogenesis. J. Biol. Chem. 294, 18714-18725. doi: 10.1074/jbc.ra119.010496

Lloyd, A., and Bomblies, K. (2016). Meiosis in autopolyploid and allopolyploid Arabidopsis. Curr. Opin. Plant Biol. 30, 116-122. doi: 10.1016/j.pbi.2016.02.004

Luboshitzky, R., Lavie, L., Shen-Orr, Z., and Herer, P. (2005). Altered luteinizing hormone and testosterone secretion in middle-aged obese men with obstructive sleep apnea. Obes. Res. 13, 780-786. doi: 10.1038/oby.2005.88

Luo, Y., Liao, W., Chen, Y., Cui, J., Liu, F., Jiang, C., et al. (2011). Altitude can alter the mtDNA copy number and nDNA integrity in sperm. J. Assist. Reprod. Genet. 28, 951-956. doi: 10.1007/s10815-011-9620-y

Lv, J. X., Zhou, J., Tong, R. Q., Wang, B., Chen, X. L., Zhuang, Y. Y., et al. (2019). Hypoxiainduced miR210 contributes to apoptosis of mouse spermatocyte GC2 cells by targeting Kruppellike factor 7. Mol. Med. Rep. 19, 271-279.

Ma, Y., Zhou, Y., Xiao, Q., Zou, S. S., Zhu, Y. C., Ping, P., et al. (2021). Seminal exosomal miR-210-3p as a potential marker of Sertoli cell damage in Varicocele. Andrology 9, 451-459. doi: 10.1111/andr.12913

Ma, Y., Zhou, Y., Zhu, Y. C., Wang, S. Q., Ping, P., and Chen, X. F. (2018). Lipophagy contributes to testosterone biosynthesis in male rat Leydig Cells. Endocrinology 159, 1119-1129. doi: 10.1210/en.2017-03020

Machogu, E. M., and Machado, R. F. (2018). How I treat hypoxia in adults with hemoglobinopathies and hemolytic disorders. Blood 132, 1770-1780. doi: 10. 1182/blood-2018-03-818195

MacIntyre, N. R. (2014). Tissue hypoxia: implications for the respiratory clinician. Respir. Care 59, 1590-1596. doi: 10.4187/respcare.03357

Madrid, E., Reyes, J. G., Hernandez, B., Garcia, J. M., San Martin, S., Olivero, P., et al. (2013). Effect of normobaric hypoxia on the testis in a murine model. Andrologia 45, 332-338. doi: 10.1111/and.12019

Madu, A. J., Ubesie, A., Ocheni, S., Chinawa, J., Madu, K. A., Ibegbulam, O. G., et al. (2014). Priapism in homozygous sickle cell patients: important clinical and laboratory associations. Med. Princ. Pract. 23, 259-263. doi: 10.1159/000360608

Majmundar, A. J., Wong, W. J., and Simon, M. C. (2010). Hypoxia-inducible factors and the response to hypoxic stress. Mol. Cell 40, 294-309. doi: 10.1016/j.molcel. 2010.09 .022
Margel, D., Cohen, M., Livne, P. M., and Pillar, G. (2004). Severe, but not mild, obstructive sleep apnea syndrome is associated with erectile dysfunction. Urology 63, 545-549. doi: 10.1016/j.urology.2003.10.016

Marques, D. A., Patrone, L. G. A., Scarpellini, C. S., Bicego, K. C., Szawka, R. E., and Gargaglioni, L. H. (2020). The role of testosterone in the respiratory and thermal responses to hypoxia and hypercapnia in rats. J. Endocrinol. 247, 101-114. doi: 10.1530/joe-20-0257

Martins, P. R., Kerbauy, J., Moraes-Souza, H., Pereira Gde, A., Figueiredo, M. S., and Verreschi, I. T. (2015). Impaired pubertal development and testicular hormone function in males with sickle cell anemia. Blood Cells Mol. Dis. 54, 29-32. doi: 10.1016/j.bcmd.2014.08.004

Mazzeo, R. S. (2005). Altitude, exercise and immune function. Exerc. Immunol. Rev. $11,6-16$.

Mesarwi, O. A., Loomba, R., and Malhotra, A. (2019). Obstructive sleep apnea, hypoxia, and nonalcoholic fatty liver disease. Am. J. Respir. Crit. Care Med. 199, 830-841. doi: 10.1164/rccm.201806-1109tr

Modebe, O., and Ezeh, U. O. (1995). Effect of age on testicular function in adult males with sickle cell anemia. Fertil. Steril. 63, 907-912. doi: 10.1016/s00150282(16)57500-1

Molinari, P. F. (1982). Erythropoietic mechanism of androgens: a critical review and clinical implications. Haematologica $67,442-460$.

Monge, M. C. (1945). Acclimatization in the Andes; Historical confirmations about the climatic aggression in the development of the societies of America. An. Fac. Med. Lima 28, 307-382.

Moreland, R. B. (1998). Is there a role of hypoxemia in penile fibrosis: a viewpoint presented to the Society for the Study of Impotence. Int. J. Impot. Res. 10, 113-120. doi: 10.1038/sj.ijir.3900328

Morimoto, H., Iwata, K., Ogonuki, N., Inoue, K., Atsuo, O., Kanatsu-Shinohara, M., et al. (2013). ROS are required for mouse spermatogonial stem cell self-renewal. Cell Stem Cell 12, 774-786. doi: 10.1016/j.stem.2013.0 4.001

Morrison, B. F., Reid, M., Madden, W., and Burnett, A. L. (2013). Testosterone replacement therapy does not promote priapism in hypogonadal men with sickle cell disease: 12-month safety report. Andrology 1, 576-582. doi: 10.1111/ j.2047-2927.2013.00084.x

Mozafari, A. A., Shahrooz, R., Ahmadi, A., Malekinjad, H., and Mardani, K. (2016). Protective effect of ethyl pyruvate on mice sperm parameters in phenylhydrazine induced hemolytic anemia. Vet. Res. Forum 7, 63-68.

Mu, Y., Yin, T. L., Yin, L., Hu, X., and Yang, J. (2018). CTRP3 attenuates high-fat diet-induced male reproductive dysfunction in mice. Clin. Sci. 132, 883-899. doi: $10.1042 / \mathrm{cs} 20180179$

Nahoum, C. R., Fontes, E. A., and Freire, F. R. (1980). Semen analysis in sickle cell disease. Andrologia 12, 542-545. doi: 10.1111/j.1439-0272.1980.tb01347.x

Nalbandian, A., Dettin, L., Dym, M., and Ravindranath, N. (2003). Expression of vascular endothelial growth factor receptors during male germ cell differentiation in the mouse. Biol. Reprod. 69, 985-994. doi: 10.1095/biolreprod. 102.013581

Narayan, P. (2015). Genetic models for the study of Luteinizing hormone receptor function. Front. Endocrinol. 6:152. doi: 10.3389/fendo.2015.00152

Neto, F. T., Bach, P. V., Najari, B. B., Li, P. S., and Goldstein, M. (2016). Spermatogenesis in humans and its affecting factors. Semin. Cell Dev. Biol. 59, 10-26. doi: 10.1016/j.semcdb.2016.04.009

Nguyen, T. T., Trieu, T. S., Tran, T. O., and Luong, T. L. A. (2019). Evaluation of sperm DNA fragmentation index, Zinc concentration and seminal parameters from infertile men with varicocele. Andrologia 51:e13184. doi: 10.1111/and. 13184

Ni, F. D., Hao, S. L., and Yang, W. X. (2019). Multiple signaling pathways in Sertoli cells: recent findings in spermatogenesis. Cell Death Dis. 10:541.

Ni, K., Steger, K., Yang, H., Wang, H., Hu, K., Zhang, T., et al. (2016). A comprehensive investigation of sperm DNA damage and oxidative stress injury in infertile patients with subclinical, normozoospermic, and astheno/oligozoospermic clinical varicocoele. Andrology 4, 816-824.

Niu, Y., DesMarais, T. L., Tong, Z., Yao, Y., and Costa, M. (2015). Oxidative stress alters global histone modification and DNA methylation. Free Radic. Biol. Med. 82, 22-28. doi: 10.1016/j.freeradbiomed.2015.01.028

Nolan, V. G., Wyszynski, D. F., Farrer, L. A., and Steinberg, M. H. (2005). Hemolysis-associated priapism in sickle cell disease. Blood 106, 3264-3267. doi: 10.1182/blood-2005-04-1594 
Oduwole, O. O., Peltoketo, H., and Huhtaniemi, I. T. (2018). Role of folliclestimulating hormone in spermatogenesis. Front. Endocrinol. 9:763. doi: 10. 3389/fendo. 2018.00763

O'Hara, L., and Smith, L. B. (2015). Androgen receptor roles in spermatogenesis and infertility. Best Pract. Res. Clin. Endocrinol. Metab. 29, 595-605. doi: 10.1016/j.beem.2015.04.006

Okumura, A., Fuse, H., Kawauchi, Y., Mizuno, I., and Akashi, T. (2003). Changes in male reproductive function after high altitude mountaineering. High Alt. Med. Biol. 4, 349-353. doi: 10.1089/15270290376919 2304

Oliva, A., and Multigner, L. (2018). Chronic epididymitis and Grade III varicocele and their associations with semen characteristics in men consulting for couple infertility. Asian J. Androl. 20, 360-365. doi: 10.4103/aja.aja_78_17

Osegbe, D. N., Akinyanju, O., and Amaku, E. O. (1981). Fertility in males with sickle cell disease. Lancet 2, 275-276. doi: 10.1016/s0140-6736(81)90525-0

Pallotti, F., Paoli, D., Carlini, T., Vestri, A. R., Martino, G., Lenzi, A., et al. (2018). Varicocele and semen quality: a retrospective case-control study of 4230 patients from a single centre. J. Endocrinol. Invest. 41, 185-192. doi: 10.1007/s40618-017-0713-z

Papageorgiou, D. P., Abidi, S. Z., Chang, H. Y., Li, X., Kato, G. J., Karniadakis, G. E., et al. (2018). Simultaneous polymerization and adhesion under hypoxia in sickle cell disease. Proc. Natl. Acad. Sci. U.S.A. 115, 9473-9478. doi: 10.1073/ pnas. 1807405115

Peacock, A. J. (1998). ABC of oxygen: oxygen at high altitude. BMJ 317, 1063-1066. doi: 10.1136/bmj.317.7165.1063

Pelliccione, F., Verratti, V., D’Angeli, A., Micillo, A., Doria, C., Pezzella, A., et al. (2011). Physical exercise at high altitude is associated with a testicular dysfunction leading to reduced sperm concentration but healthy sperm quality. Fertil. Steril. 96, 28-33. doi: 10.1016/j.fertnstert.2011.03.111

Perera, D., Pizzey, A., Campbell, A., Katz, M., Porter, J., Petrou, M., et al. (2002). Sperm DNA damage in potentially fertile homozygous beta-thalassaemia patients with iron overload. Hum. Reprod. 17, 1820-1825. doi: 10.1093/ humrep/17.7.1820

Powell, J. D., Elshtein, R., Forest, D. J., and Palladino, M. A. (2002). Stimulation of hypoxia-inducible factor-1 alpha (HIF-1alpha) protein in the adult rat testis following ischemic injury occurs without an increase in HIF-1alpha messenger RNA expression. Biol. Reprod. 67, 995-1002. doi: 10.1095/biolreprod.101. 002576

Practice Committee of the American Society for Reproductive Medicine (2015). Diagnostic evaluation of the infertile male: a committee opinion. Fertil. Steril. 103, e18-e25.

Raff, H., Hoeynck, B., Jablonski, M., Leonovicz, C., Phillips, J. M., and Gehrand, A. L. (2018). Insulin sensitivity, leptin, adiponectin, resistin, and testosterone in adult male and female rats after maternal-neonatal separation and environmental stress. Am. J. Physiol. Regul. Integr. Comp. Physiol. 314, R12-R21.

Rajender, S., Avery, K., and Agarwal, A. (2011). Epigenetics, spermatogenesis and male infertility. Mutat. Res. 727, 62-71.

Rathore, C., Henning, O. J., Luef, G., and Radhakrishnan, K. (2019). Sexual dysfunction in people with epilepsy. Epilepsy Behav. 100:106495. doi: 10.1016/ j.yebeh.2019.106495

Redmon, J. B., Drobnis, E. Z., Sparks, A., Wang, C., and Swan, S. H. (2019). Semen and reproductive hormone parameters in fertile men with and without varicocele. Andrologia 51:e13407.

Ren, H., and Hu, K. (2017). Inflammatory and oxidative stressassociated factors in chronic intermittent hypoxia in Chinese patients, rats, lymphocytes and endotheliocytes. Mol. Med. Rep. 16, 8092-8102. doi: 10.3892/mmr.2017.7632

Reyes, J. G., Farias, J. G., Henriquez-Olavarrieta, S., Madrid, E., Parraga, M., Zepeda, A. B., et al. (2012). The hypoxic testicle: physiology and pathophysiology. Oxid. Med. Cell. Longev. 2012:929285.

Rius, J., Guma, M., Schachtrup, C., Akassoglou, K., Zinkernagel, A. S., Nizet, V., et al. (2008). NF-kappaB links innate immunity to the hypoxic response through transcriptional regulation of HIF-1alpha. Nature 453, 807-811. doi: 10.1038 /nature06905

Rubinsztajn, R., Przybylowski, T., Maskey-Warzechowska, M., Karwat, K., and Chazan, R. (2019). Serum testosterone depression as a factor influencing the general condition in chronic obstructive pulmonary disease patients. Adv. Clin. Exp. Med. 28, 783-788. doi: 10.17219/acem/94153
Ryall, J. G., Cliff, T., Dalton, S., and Sartorelli, V. (2015). Metabolic reprogramming of stem cell epigenetics. Cell Stem Cell 17, 651-662. doi: 10.1016/j.stem.2015.11. 012

S, K. S. S., Veeramohan, P. H., Mathew, T., S, S., and M, C. (2012). Nifedipine inhibits hypoxia induced transvascular leakage through down regulation of NFkB. Respir. Physiol. Neurobiol. 183, 26-34. doi: 10.1016/j.resp.2012.05.016

Saenz de Tejada, I., Angulo, J., Cellek, S., Gonzalez-Cadavid, N., Heaton, J., et al. (2004). Physiology of erectile function. J. Sex. Med. 1, 254-265.

Safarinejad, M. R. (2008a). Evaluation of endocrine profile, hypothalamicpituitary-testis axis and semen quality in multiple sclerosis. J. Neuroendocrinol. 20, 1368-1375. doi: 10.1111/j.1365-2826.2008.01791.x

Safarinejad, M. R. (2008b). Evaluation of semen quality, endocrine profile and hypothalamus-pituitary-testis axis in male patients with homozygous betathalassemia major. J. Urol. 179, 2327-2332. doi: 10.1016/j.juro.2008.01.103

Salonia, A., Eardley, I., Giuliano, F., Hatzichristou, D., Moncada, I., Vardi, Y., et al. (2014). European Association of Urology guidelines on priapism. Eur. Urol. 65, 480-489. doi: 10.1016/j.eururo.2013.11.008

Samanta, L., Agarwal, A., Swain, N., Sharma, R., Gopalan, B., Esteves, S. C., et al. (2018). Proteomic signatures of sperm mitochondria in varicocele: clinical use as biomarkers of varicocele associated infertility. J. Urol. 200, 414-422. doi: 10.1016/j.juro.2018.03.009

Santamaria, J. D., Prior, J. C., and Fleetham, J. A. (1988). Reversible reproductive dysfunction in men with obstructive sleep apnoea. Clin. Endocrinol. 28, 461470. doi: 10.1111/j.1365-2265.1988.tb03680.x

Santana, V. P., James, E. R., Miranda-Furtado, C. L., Souza, M. F., Pompeu, C. P., Esteves, S. C., et al. (2020). Differential DNA methylation pattern and sperm quality in men with varicocele. Fertil. Steril. 114, 770-778. doi: 10.1016/j. fertnstert.2020.04.045

Santana, V. P., Miranda-Furtado, C. L., Pedroso, D. C. C., Eiras, M. C., Vasconcelos, M. A. C., Ramos, E. S., et al. (2019). The relationship among sperm global DNA methylation, telomere length, and DNA fragmentation in varicocele: a cross-sectional study of 20 cases. Syst. Biol. Reprod. Med. 65, 95-104. doi: 10.1080/19396368.2018.1557762

Santi, D., De Vincentis, S., Magnani, E., and Spaggiari, G. (2017). Impairment of sperm DNA methylation in male infertility: a meta-analytic study. Andrology 5, 695-703. doi: 10.1111/andr.12379

Sar, M., Lubahn, D. B., French, F. S., and Wilson, E. M. (1990). Immunohistochemical localization of the androgen receptor in rat and human tissues. Endocrinology 127, 3180-3186. doi: 10.1210/endo-127-6-3180

Saxena, D. K. (1995). Effect of hypoxia by intermittent altitude exposure on semen characteristics and testicular morphology of male rhesus monkeys. Int. J. Biometeorol. 38, 137-140. doi: 10.1007/bf01208490

Schisterman, E. F., Sjaarda, L. A., Clemons, T., Carrell, D. T., Perkins, N. J., Johnstone, E., et al. (2020). Effect of folic acid and zinc supplementation in men on semen quality and live birth among couples undergoing infertility treatment: a randomized clinical trial. JAMA 323, 35-48. doi: 10.1001/jama.2019.18714

Schneider, S., Shakeri, F., Trotschel, C., Arevalo, L., Kruse, A., Buness, A., et al. (2020). Protamine-2 deficiency initiates a reactive oxygen species (ROS)mediated destruction cascade during epididymal sperm maturation in mice. Cells 9:1789. doi: 10.3390/cells9081789

Semenza, G. L. (2012). Hypoxia-inducible factors in physiology and medicine. Cell 148, 399-408. doi: 10.1016/j.cell.2012.01.021

Semple, P. A., Graham, A., Malcolm, Y., Beastall, G. H., and Watson, W. S. (1984). Hypoxia, depression of testosterone, and impotence in pickwickian syndrome reversed by weight reduction. Br. Med. J. 289, 801-802. doi: 10.1136/bmj.289. 6448.801

Semple, P. D., Beastall, G. H., Brown, T. M., Stirling, K. W., Mills, R. J., and Watson, W. S. (1984). Sex hormone suppression and sexual impotence in hypoxic pulmonary fibrosis. Thorax $39,46-51$. doi: 10.1136/thx.39.1.46

Semple, P. D., Beastall, G. H., Watson, W. S., and Hume, R. (1981). Hypothalamicpituitary dysfunction in respiratory hypoxia. Thorax 36, 605-609. doi: 10.1136/ thx.36.8.605

Semple, P. D., Brown, T. M., Beastall, G. H., and Semple, C. G. (1983). Sexual dysfunction and erectile impotence in chronic obstructive pulmonary disease. Chest 83, 587-588. doi: 10.1378/chest.83.3.587b

Shaha, C., Tripathi, R., and Mishra, D. P. (2010). Male germ cell apoptosis: regulation and biology. Philos. Trans. R. Soc. Lond. B Biol. Sci. 365, 1501-1515. doi: $10.1098 /$ rstb.2009.0124 
Shamloul, R., and Ghanem, H. (2013). Erectile dysfunction. Lancet 381, 153-165. Sharma, P., Ghanghas, P., Kaushal, N., Kaur, J., and Kaur, P. (2019). Epigenetics and oxidative stress: a twin-edged sword in spermatogenesis. Andrologia 51:e13432.

Shevantaeva, O. N., and Kosyuga, Y. I. (2006). Effect of acute hypobaric hypoxia on spermatogenesis and lactate concentration in testicular tissue of male albino rats. Bull. Exp. Biol. Med. 141, 20-22. doi: 10.1007/s10517-006-0 082-7

Shin, H. W., Rha, Y. C., Han, D. H., Chung, S., Yoon, I. Y., Rhee, C. S., et al. (2008). Erectile dysfunction and disease-specific quality of life in patients with obstructive sleep apnea. Int. J. Impot. Res. 20, 549-553. doi: 10.1038/ijir.2008.39

Smith, L. B., and Walker, W. H. (2014). The regulation of spermatogenesis by androgens. Semin. Cell Dev. Biol. 30, 2-13. doi: 10.1016/j.semcdb.2014.02.012

Soukhova-O'Hare, G. K., Shah, Z. A., Lei, Z., Nozdrachev, A. D., Rao, C. V., and Gozal, D. (2008). Erectile dysfunction in a murine model of sleep apnea. Am. J. Respir. Crit. Care Med. 178, 644-650.

Stannek, T., Hurny, C., Schoch, O. D., Bucher, T., and Munzer, T. (2009). Factors affecting self-reported sexuality in men with obstructive sleep apnea syndrome. J. Sex. Med. 6, 3415-3424. doi: 10.1111/j.1743-6109.2009.01486.x

Sun, H., Gong, T. T., Jiang, Y. T., Zhang, S., Zhao, Y. H., and Wu, Q. J. (2019). Global, regional, and national prevalence and disability-adjusted life-years for infertility in 195 countries and territories, 1990-2017: results from a global burden of disease study, 2017. Aging 11, 10952-10991. doi: 10.18632/aging. 102497

Svartberg, J., Schirmer, H., Medbo, A., Melbye, H., and Aasebo, U. (2007). Reduced pulmonary function is associated with lower levels of endogenous total and free testosterone, The Tromso study. Eur. J. Epidemiol. 22, 107-112. doi: 10.1007/ s10654-006-9095-9

Taddesse, A., Woldie, I. L., Khana, P., Swerdlow, P. S., Chu, J. W., Abrams, J., et al. (2012). Hypogonadism in patients with sickle cell disease: central or peripheral? Acta Haematol. 128, 65-68. doi: 10.1159/000337344

Tahamtan, S., Tavalaee, M., Izadi, T., Barikrow, N., Zakeri, Z., Lockshin, R. A., et al. (2019). Reduced sperm telomere length in individuals with varicocele is associated with reduced genomic integrity. Sci. Rep. 9:4336.

Tai, P., and Ascoli, M. (2011). Reactive oxygen species (ROS) play a critical role in the cAMP-induced activation of Ras and the phosphorylation of ERK1/2 in Leydig cells. Mol. Endocrinol. 25, 885-893. doi: 10.1210/me.2010-0489

Tanaka, T., Kobori, Y., Terai, K., Inoue, Y., Osaka, A., Yoshikawa, N., et al. (2020). Seminal oxidation-reduction potential and sperm DNA fragmentation index increase among infertile men with varicocele. Hum. Fertil. doi: 10.1080/ 14647273.2020.1712747 [Epub ahead of print].

Tapanainen, J. S., Aittomaki, K., Min, J., Vaskivuo, T., and Huhtaniemi, I. T. (1997). Men homozygous for an inactivating mutation of the follicle-stimulating hormone (FSH) receptor gene present variable suppression of spermatogenesis and fertility. Nat. Genet. 15, 205-206. doi: 10.1038/ng0297-205

Thomason, A. M., and Fariss, B. L. (1979). The prevalence of varicoceles in a group of healthy young men. Mil. Med. 144, 181-182. doi: 10.1093/milmed/144.3.181

Torres, M., Laguna-Barraza, R., Dalmases, M., Calle, A., Pericuesta, E., Montserrat, J. M., et al. (2014). Male fertility is reduced by chronic intermittent hypoxia mimicking sleep apnea in mice. Sleep 37, 1757-1765. doi: 10.5665/sleep.4166

Tournaye, H., Krausz, C., and Oates, R. D. (2017). Novel concepts in the aetiology of male reproductive impairment. Lancet Diabetes Endocrinol. 5, 544-553. doi: $10.1016 / \mathrm{s} 2213-8587(16) 30040-7$

Tremellen, K. (2008). Oxidative stress and male infertility-a clinical perspective. Hum. Reprod. Update 14, 243-258. doi: 10.1093/humupd/dmn004

Van Vliet, M., Spruit, M. A., Verleden, G., Kasran, A., Van Herck, E., Pitta, F., et al. (2005). Hypogonadism, quadriceps weakness, and exercise intolerance in chronic obstructive pulmonary disease. Am. J. Respir. Crit. Care Med. 172, 1105-1111. doi: 10.1164/rccm.200501-114oc

Vargas, A., Bustos-Obregon, E., and Hartley, R. (2011). Effects of hypoxia on epididymal sperm parameters and protective role of ibuprofen and melatonin. Biol. Res. 44, 161-167. doi: 10.4067/s0716-97602011000200008

Verratti, V., Berardinelli, F., Di Giulio, C., Bosco, G., Cacchio, M., Pellicciotta, M., et al. (2008). Evidence that chronic hypoxia causes reversible impairment on male fertility. Asian J. Androl. 10, 602-606. doi: 10.1111/j.1745-7262.2008. 00346.x

Verratti, V., Di Giulio, C., D’Angeli, A., Tafuri, A., Francavilla, S., and Pelliccione, F. (2016). Sperm forward motility is negatively affected by short-term exposure to altitude hypoxia. Andrologia 48, 800-806. doi: 10.1111/and.12515
Vgontzas, A. N., Papanicolaou, D. A., Bixler, E. O., Hopper, K., Lotsikas, A., Lin, H. M., et al. (2000). Sleep apnea and daytime sleepiness and fatigue: relation to visceral obesity, insulin resistance, and hypercytokinemia. J. Clin. Endocrinol. Metab. 85, 1151-1158. doi: 10.1210/jcem.85.3.6484

Vieira, H. R., Goncalves, G. D., Vieira, N. A., Erthal, R. P., Sampaio, C. F., Pinto, I. C., et al. (2020). Pulmonary emphysema impairs male reproductive physiology due to testosterone and oxidative stress imbalance in Mesocricetus auratus. Reprod. Sci. 27, 2052-2062. doi: 10.1007/s43032-020-00224-4

Wang, D., Zhao, W., Liu, J., Wang, Y., Yuan, C., Zhang, F., et al. (2020). Effects of HIF-1alpha on spermatogenesis of varicocele rats by regulating VEGF/PI3K/Akt Signaling Pathway. Reprod. Sci. 28, 1161-1174. doi: 10.1007/ s43032-020-00395-0

Wang, G. L., Jiang, B. H., Rue, E. A., and Semenza, G. L. (1995). Hypoxia-inducible factor 1 is a basic-helix-loop-helix-PAS heterodimer regulated by cellular O2 tension. Proc. Natl. Acad. Sci. U.S.A. 92, 5510-5514. doi: 10.1073/pnas.92.12. 5510

Wang, J., Gong, X., Meng, F., Deng, S., Dai, H., Bao, B., et al. (2020). Biological network model of effect of chronic intermittent hypoxia on spermatogenesis in rats. Med. Sci. Monit. 26:e925579.

Wang, R. S., Yeh, S., Tzeng, C. R., and Chang, C. (2009). Androgen receptor roles in spermatogenesis and fertility: lessons from testicular cell-specific androgen receptor knockout mice. Endocr. Rev. 30, 119-132. doi: 10.1210/er.2008-0025

Wang, S. Y., Lau, K., Lai, K. P., Zhang, J. W., Tse, A. C., Li, J. W., et al. (2016). Hypoxia causes transgenerational impairments in reproduction of fish. Nat. Commun. 7:12114.

Wang, X., Jin, L., Jiang, S., Wang, D., Lu, Y., and Zhu, L. (2019). Transcription regulation of NRF1 on StAR reduces testosterone synthesis in hypoxemic murine. J. Steroid Biochem. Mol. Biol. 191, 105370. doi: 10.1016/j.jsbmb.2019. 04.019

Wang, X., Pan, L., Zou, Z., Wang, D., Lu, Y., Dong, Z., et al. (2017). Hypoxia reduces testosterone synthesis in mouse Leydig cells by inhibiting NRF1-activated StAR expression. Oncotarget 8, 16401-16413. doi: 10.18632/ oncotarget. 14842

Wang, X., Zou, Z., Yang, Z., Jiang, S., Lu, Y., Wang, D., et al. (2018). HIF 1 inhibits StAR transcription and testosterone synthesis in murine Leydig cells. J. Mol. Endocrinol. doi: 10.1530/JME-18-0148

Wenger, R. H., and Katschinski, D. M. (2005). The hypoxic testis and post-meiotic expression of PAS domain proteins. Semin. Cell Dev. Biol. 16, 547-553. doi: 10.1016/j.semcdb.2005.03.008

World Health Organization (WHO) (2010). WHO Laboratory Manual for the Examination, and Processing of Human Semen. Geneva: WHO.

Yadav, A. K., Yadav, P. K., Chaudhary, G. R., Tiwari, M., Gupta, A., Sharma, A., et al. (2019). Autophagy in hypoxic ovary. Cell. Mol. Life Sci. 76, 3311-3322.

Yafi, F. A., Jenkins, L., Albersen, M., Corona, G., Isidori, A. M., Goldfarb, S., et al. (2016). Erectile dysfunction. Nat. Rev. Dis. Primers 2:16003.

Yeh, J. R., Zhang, X., and Nagano, M. C. (2011). Wnt5a is a cell-extrinsic factor that supports self-renewal of mouse spermatogonial stem cells. J. Cell Sci. 124, 2357-2366. doi: 10.1242/jcs.080903

Yin, J., Ni, B., Liao, W. G., and Gao, Y. Q. (2018a). Hypoxia-induced apoptosis of mouse spermatocytes is mediated by HIF-1alpha through a death receptor pathway and a mitochondrial pathway. J. Cell. Physiol. 233, 1146-1155. doi: $10.1002 / j c p .25974$

Yin, J., Ni, B., Yang, Y. D., Tang, Z. W., Gao, Z. Q., Feng, L., et al. (2018b). Elevation of autophagy rescues spermatogenesis by inhibiting apoptosis of mouse spermatocytes. Reproduction 156, 545-558.

Yokoe, T., Minoguchi, K., Matsuo, H., Oda, N., Minoguchi, H., Yoshino, G., et al. (2003). Elevated levels of C-reactive protein and interleukin-6 in patients with obstructive sleep apnea syndrome are decreased by nasal continuous positive airway pressure. Circulation 107, 1129-1134. doi: 10.1161/01.cir.0000052627. 99976.18

Zegers-Hochschild, F., Adamson, G. D., de Mouzon, J., Ishihara, O., Mansour, R., Nygren, K., et al. (2009). International Committee for Monitoring Assisted Reproductive Technology (ICMART) and the World Health Organization (WHO) revised glossary of ART terminology, 2009. Fertil. Steril. 92, 1520-1524. doi: 10.1016/j.fertnstert.2009.09.009

Zhang, K., Wang, Z., Wang, H., Fu, Q., Zhang, H., and Cao, Q. (2016). Hypoxiainduced apoptosis and mechanism of epididymal dysfunction in rats with left-side varicocele. Andrologia 48, 318-324. doi: 10.1111/and.12449 
Zhang, Y., Ma, T., Su, Z., Ye, M., Tian, H., Li, J., et al. (2017). Varicoceles affect semen quality of infertile men in Southern China: a cross-sectional study of 5447 cases. Medicine 96:e7707. doi: 10.1097/md.00000000000 07707

Zhao, J. L., Zhao, Y. Y., and Zhu, W. J. (2017). A high-fat, high-protein diet attenuates the negative impact of casein-induced chronic inflammation on testicular steroidogenesis and sperm parameters in adult mice. Gen. Comp. Endocrinol. 252, 48-59. doi: 10.1016/j.ygcen.2017.07.013

Zhao, R. Z., Wang, X. B., Jiang, S., Ru, N. Y., Jiao, B., Wang, Y. Y., et al. (2020). Elevated ROS depress mitochondrial oxygen utilization efficiency in cardiomyocytes during acute hypoxia. Pflugers Arch. 472, 1619-1630. doi: 10.1007/s00424-020-02463-5

Zhao, W., Liu, J., Wang, D., Wang, Y., Zhang, F., Jin, G., et al. (2019). Effect of silencing HIF-1alpha gene on testicle spermatogenesis function in varicocele rats. Cell Tissue Res. 378, 543-554. doi: 10.1007/s00441-019-03064-0

Zheng, S., Liu, Y., Li, P., and Tian, H. (2019). Short-term high-altitude exposure $(3600 \mathrm{~m})$ alters the type distribution of sperm deformity. High Alt. Med. Biol. 20, 198-202. doi: 10.1089/ham.2018.0133

Zhou, J., Qian, C. Y., Tong, R. Q., Wang, B., Chen, X. L., Zhuang, Y. Y., et al. (2018). Hypoxia induces apoptosis of mouse spermatocyte GC-2 cells through activation of autophagy. Cell Biol. Int. 42, 1124-1131. doi: 10.1002/cbin.10971

Zhu, D., Deng, Y., Pan, Y., Wang, Z., Yuan, X., Guo, X., et al. (2015). $\mathrm{N}$-acetylcysteine ameliorates the erectile dysfunction caused by chronic intermittent hypoxia in rats: partly involvement of endoplasmic reticulum stress. Urology 86, 844.e7-844.e14.

Zhu, S. M., Rao, T., Yang, X., Ning, J. Z., Yu, W. M., Ruan, Y., et al. (2017). Autophagy may play an important role in varicocele. Mol. Med. Rep. 16, 5471-5479. doi: 10.3892/mmr.2017.7253

Conflict of Interest: The authors declare that the research was conducted in the absence of any commercial or financial relationships that could be construed as a potential conflict of interest.

Publisher's Note: All claims expressed in this article are solely those of the authors and do not necessarily represent those of their affiliated organizations, or those of the publisher, the editors and the reviewers. Any product that may be evaluated in this article, or claim that may be made by its manufacturer, is not guaranteed or endorsed by the publisher.

Copyright (c) 2021 Li, Wang, Gong, Hu, Liu, Wang, Chen, Liao, He, Huang, Luo, Zhao and Xiao. This is an open-access article distributed under the terms of the Creative Commons Attribution License (CC BY). The use, distribution or reproduction in other forums is permitted, provided the original author(s) and the copyright owner(s) are credited and that the original publication in this journal is cited, in accordance with accepted academic practice. No use, distribution or reproduction is permitted which does not comply with these terms. 